\title{
Conformational-Dependent and Independent RNA Binding to the Fragile X Mental Retardation Protein
}

\author{
Xin Yan $^{1}$ and Robert B. Denman ${ }^{2}$ \\ ${ }^{1}$ CSI/IBR Center for Developmental Neuroscience, College of Staten Island, City University of New York, Staten Island, \\ NY 10314, USA \\ ${ }^{2}$ Biochemical Molecular Neurobiology Laboratory, Department of Molecular Biology, New York State Institute for Basic Research in \\ Developmental Disabilities, 1050 Forest Hill Road, Staten Island, NY 10314, USA
}

Correspondence should be addressed to Robert B. Denman, rbdenman@yahoo.com

Received 8 October 2010; Accepted 16 March 2011

Academic Editor: Dmitry A. Stetsenko

Copyright (๑) 2011 X. Yan and R. B. Denman. This is an open access article distributed under the Creative Commons Attribution License, which permits unrestricted use, distribution, and reproduction in any medium, provided the original work is properly cited.

\begin{abstract}
The interaction between the fragile X mental retardation protein (FMRP) and BC1 RNA has been the subject of controversy. We probed the parameters of RNA binding to FMRP in several ways. Nondenaturing agarose gel analysis showed that BC1 RNA transcripts produced by in vitro transcription contain a population of conformers, which can be modulated by preannealing. Accordingly, FMRP differentially binds to the annealed and unannealed conformer populations. Using partial RNase digestion, we demonstrate that annealed BC1 RNA contains a unique conformer that FMRP likely binds. We further demonstrate that this interaction is 100-fold weaker than that the binding of eEF-1A mRNA and FMRP, and that preannealing is not a general requirement for FMRP's interaction with RNA. In addition, binding does not require the N-terminal 204 amino acids of FMRP, methylated arginine residues and can be recapitulated by both fragile X paralogs. Altogether, our data continue to support a model in which BC1 RNA functions independently of FMRP.
\end{abstract}

\section{Introduction}

Fragile $\mathrm{X}$ syndrome is the most common inherited cause of mental impairment accounting for ca. $40 \%$ of X-linked mental retardation cases. It is also the most common known cause of autism (reviewed in [1-6]). Other characteristics of the fragile X syndrome include hyperactivity [7], increased susceptibility to seizures [8], increased testicular volume [9], macrocephaly, and large ears [10]. In addition, it has been found that carriers of the fragile $\mathrm{X}$ premutation, once thought to be free of the effects of the disease, also suffer from subtle behavioral and physical abnormalities [11-14]. This wide and varied constellation of phenotypic features results from the loss of function of a single gene, FMR1 (summarized in: http://www.ncbi.nlm.nih.gov/ bookshelf/br.fcgi?book=gene\&part-fragilex).

The FMR1 gene encodes the RNA-binding protein FMRP [15], a negative [16-18] and positive $[19,20]$ translational regulator, and it has been of considerable interest to delineate the cellular RNAs that bind to FMRP [21-25] and the mechanism(s) by which FMRP binds and controls these mRNAs [26-35].

In 2003, Zalfa et al. described a bridging mechanism in which the fragile $\mathrm{X}$ mental retardation protein (FMRP) via interaction with the $5^{\prime}$ end of the small noncoding RNA, BC1, and bound and repressed FMRP target mRNAs [36]. This model has been subject to great deal of scrutiny owing to findings that appear to be out of step with other studies. These include differences in the prime localization of FMRP with small repressed mRNPs rather than brain polyribosomes [18,37-39], differences in the interpretation of the interaction of FMRP with BC1 RNA as specific and significant [40] rather than nonspecific and insignificant [30, $41,42]$ and detailed mechanistic differences in the nature of BC1 RNA-mediated localization and translational repression $[41,43-45]$. In response to some of these criticisms, Zalfa 
and Bagni reposited that their model, rather than being a general model of FMRP-mRNA interactions, was only one of several possible models [46].

More recent investigations of some of the concomitants of the Zalfa model [47] found that the interaction of recombinant FMRP with BC1 RNA was weak compared to that of a G-quartet-containing RNA. Furthermore, its strength varied significantly depending upon the buffer conditions used. The data suggested that FMRP may interact with a particular conformer of BC1 RNA. Here, we elaborate the conditions and requirements for a weak FMRP BC1 RNA in vitro interaction.

\section{Materials and Methods}

2.1. Buffers. Z-buffer is $10 \mathrm{mM}$ Tris- $\mathrm{HCl} \mathrm{pH} \quad 7.5$, $2 \mathrm{mM} \mathrm{MgCl}_{2}, \quad 400 \mathrm{mM} \mathrm{NaCl}$ and $0.2 \%$ SDS [36]. The RNA-binding buffer that was used for affinity capture is $50 \mathrm{mM}$ Tris- $\mathrm{HCl}, \mathrm{pH} 7.4,2 \mathrm{mM} \mathrm{MgCl}_{2}$, and $150 \mathrm{mM} \mathrm{KCl}$, $1 \mathrm{mM}$ EDTA, and $1 \mathrm{mM}$ DTT [26]. Structure buffer is $10 \mathrm{mM}$ Tris- $\mathrm{HCl} \mathrm{pH} \mathrm{7,} 100 \mathrm{mM} \mathrm{KCl}$, and $10 \mathrm{mM} \mathrm{MgCl}_{2}$.

2.2. Preparation of BC1 RNA Transcripts. Dra I linearized pBCX607 containing the entire BC1 sequence [48], AvaII linearized pBCX607 containing the first $65 \mathrm{~b}$ of BC1, Sac I linearized pMK-1 containing the last $60 \mathrm{~b}$ of BC1 RNA, a PCR fragment encoding a T7 RNA polymerase promoter and the first $75 \mathrm{~b}$ of BC1 RNA, Hind III linearized pTAR encoding an $85 \mathrm{~b}$ transcript that folds into a $57 \mathrm{~b}$ TAR element and a $28 \mathrm{~b}$ leader sequence and linearized pTri-XEF1 encoding eEF-1A mRNA (Ambion) were used to produce biotinylated RNAs via in vitro transcription (Ambion). Plasmids pBCX607 and pMK-1 were provided by Dr. Henri Tiedge (SUNY Brooklyn). Alcohol-precipitated RNAs were dissolved in $50 \mu \mathrm{L}$ DEPC-treated $\mathrm{H}_{2} \mathrm{O}$ and quantified spectrophotometrically. RNA integrity was examined by agarose gel electrophoresis. For examining the effect of annealing on RNA-protein interactions, individual RNAs were heated in $1 \mathrm{x}$ transcription buffer (Ambion) at $65^{\circ} \mathrm{C}$ for $10 \mathrm{~min}$ and then allowed to cool slowly to room temperature for one hour prior to their use. Note. We obtained identical results using Z-buffer in the annealing reaction (not shown).

2.3. RNA-Binding Assays. ${ }^{35} \mathrm{~S}-\mathrm{FMRP},{ }^{35} \mathrm{~S}-\mathrm{FMRP}_{280},{ }^{35} \mathrm{~S}-$ FMRP $_{204},{ }^{35} \mathrm{~S}$-FXR1P, ${ }^{35} \mathrm{~S}$-FXR2P, ${ }^{35} \mathrm{~S}$-eIF4A, and ${ }^{35} \mathrm{~S}$ luciferase and were produced from plasmids pET21A-FMRP, pND-L-mHisFMRP, pET9-FMRP ${ }_{280}$, pET9-FMRP ${ }_{204}$, pHAFXR1P, and pET21b-FXR2P in an RRL-coupled transcription-translation system (Promega). Plasmid pHA-FXR1P was provided by Dr. Gideon Dreyfuss (University of Pennsylvania); plasmids pET9-FMRP 280 and pET9-FMRP 204 were provided by Dr. Darryl Spinner (IBR), plasmid pET21bFXR2P was a gift from Dr. Jennifer Darnell (Rockefeller University) and plasmid pET-His6-eIF4A was a gift from Dr. Henri Tiedge (SUNY Brooklyn). Briefly, ${ }^{35}$ S-labeledproteins were produced by combining twenty five microliters of TNT rabbit reticulocyte lysate (RRL) with $2 \mu \mathrm{L}$ of TNT T7 RNA polymerase, $1 \mu \mathrm{L}$ of $1 \mathrm{mM}$ amino acid mix minusmethionine, $35 \mu \mathrm{Ci}$ of ${ }^{35} \mathrm{~S}$-methionine, $1 \mu \mathrm{L}$ of RNasin and
$1 \mu \mathrm{g}$ of plasmid DNA in a total volume of $50 \mu \mathrm{L}$. One microliter of a 50X Complete protease inhibitor cocktail was added to prevent proteolysis. Samples were incubated at $30^{\circ} \mathrm{C}$ for $90 \mathrm{~min}$ and then assayed for protein production by autoradiography.

Affinity capture assays were performed as described previously [17]; the bound and unbound products were resolved by SDS-PAGE and subject to autoradiography.

Autoradiograms were quantified using UN-SCAN-IT Gel 6.1 (Silk Scientific, Inc.). The percent binding was calculated as

$$
\% \text { Binding }=100 \times \frac{\text { Intensity }_{\text {bound }}}{\left[\text { Intensity }_{\text {bound }}+\text { Intensity }_{\text {unbound }}\right]} \text {. }
$$

The percent binding of the "no RNA" control in each experimental set was subtracted from that of the samples; the difference, representing authentic binding, was plotted.

2.4. RNA Structure Studies. Annealed and unannealed BC1 RNA, BC1 fragment RNAs and control RNAs (1-2 $\mu \mathrm{g})$, were treated at room temperature for $15 \mathrm{~min}$ with various amounts of ribonuclease V1 (cobra venom) or ribonuclease A in structure buffer as indicated. Reaction products were resolved on $1-2 \%$ TAE agarose gels containing $0.1 \mu \mathrm{g} / \mathrm{mL}$ ethidium bromide along with appropriate size markers. Gels were imaged using a Scion CFW-1308 M mega pixel camera and captured in inverted mode using FOTO/Analyst PC Image software version 9.04 (FOTODYNE). The resulting image files were digitized and analyzed using UN-SCAN-IT Gel 6.1.

2.5. RNA Secondary Structure Modeling. RNA lowest energy secondary structures were determined using the Zuker algorithm, M-fold (http://mfold.rna.albany.edu).

\section{Results and Discussion}

3.1. Affinity Capture of FMRP with Biotinylated RNA. Several methods have been used to assess the direct physical interaction of FMRP with RNA in vitro. These include pulldown assays with homoribopolymers [15, 21, 49, 50], affinity capture using biotinylated RNA [21, 41, 51-53], affinity capture using immobilized protein [16], UV crosslinking $[21,49]$, filter-binding assays [22, 30, 41], electrophoretic mobility shift assays (EMSA) [26, 36, 40, 42, 47, 54], and agarose electrophoretic mobility shift assays (AGESA) [17, 41]. Each of these methods has its unique experimental advantages [55]. Acknowledging that binding between a nucleic acid and RNA-binding protein (RBP) can be affected by differences in posttranslational modification [56] and/or differences between different protein variants $[57,58]$ our working hypothesis is that given a particular RBP, a particular RNA and a defined buffer each of these methods should converge to produce a common answer. While extensively studied, FMRP's interactions with RNA have not always been examined with this hypothesis in mind Table 1, and it has been suggested that differences in experimental conditions 
TABLE 1: Binding conditions used to measure the interaction between FMRP and RNA.

\begin{tabular}{|c|c|c|}
\hline Publication & Assay & Conditions \\
\hline Ashley et al. (1993) [51] & Pull-down & $\begin{array}{l}16 \mathrm{mM} \text { HEPES-KOH pH 7.9, } 120 \mathrm{mM} \mathrm{KCI}, 0.04 \% \text { Nonidet P- } 40,1 \mathrm{mg} / \mathrm{mL} \mathrm{BSA} \text {, } \\
0.16 \mathrm{mM} \text { dithioerythritol, } 0.4 \mathrm{mM} \text { phenylmethylsulfonyl fluoride }\end{array}$ \\
\hline Brown et al. (1998) [49] & Pull-down & $\begin{array}{l}10 \mathrm{mM} \text { Tris- } \mathrm{HCl} \mathrm{pH} 7.5,2.5 \mathrm{mM} \mathrm{MgCl} 2,100 \mathrm{mM} \mathrm{NaCl}, 2.5 \% \text { Trition X100, } \\
1 \mathrm{mg} / \mathrm{mL} \text { heparin }\end{array}$ \\
\hline Price et al. (1996) [52] & Pull-down & $\begin{array}{l}20 \mathrm{mM} \text { Hepes, pH 7.9, } 2 \mathrm{mM} \mathrm{MgCl}_{2}, 10 \mathrm{mM} \mathrm{ZnCl}_{2}, 70 \mathrm{mM} \mathrm{NH}_{4} \mathrm{Cl}, 0.02 \% \text { Nonidet } \\
\text { P-40, } 5 \mathrm{mg} / \mathrm{mL} \text { yeast tRNA }\end{array}$ \\
\hline Sung et al. (2000) [21] & $\begin{array}{c}\text { Pull-down } \\
\text { Filter-Binding }\end{array}$ & $\begin{array}{l}20 \mathrm{mM} \text { Hepes, } \mathrm{pH} 7.9,2 \mathrm{mM} \mathrm{MgCl}_{2}, 10 \mathrm{mM} \mathrm{ZnCl}_{2}, 70 \mathrm{mM} \mathrm{NH}_{4} \mathrm{Cl}, 0.02 \% \text { Nonidet } \\
\text { P-40, } 5 \mathrm{mg} / \mathrm{mL} \text { yeast tRNA }\end{array}$ \\
\hline $\begin{array}{l}\text { Denman and Sung (2002) } \\
\text { [57] }\end{array}$ & Pull-down & $\begin{array}{l}20 \mathrm{mM} \text { Hepes, pH 7.9, } 2 \mathrm{mM} \mathrm{MgCl}_{2}, 10 \mathrm{mM} \mathrm{ZnCl}_{2}, 70 \mathrm{mM} \mathrm{NH}_{4} \mathrm{Cl}, 0.02 \% \text { Nonidet } \\
\text { P-40, } 5 \mathrm{mg} / \mathrm{mL} \text { yeast tRNA }\end{array}$ \\
\hline Schaeffer et al. (2001) [26] & EMSA & $\begin{array}{l}50 \mathrm{mM} \text { Tris- } \mathrm{HCl} \mathrm{pH} \text { 7.4, } 1 \mathrm{mM} \mathrm{MgCl}, 1 \mathrm{mM} \text { EDTA, } 150 \mathrm{mM} \mathrm{KCl}, 1 \mathrm{mM} \mathrm{DTT} \text {, } \\
0.25 \mathrm{mg} / \mathrm{mL} \text { of E.coli tRNA, } 0.01 \% \text { BSA, } 8 \mathrm{U} \text { of RNasin }\end{array}$ \\
\hline Sung et al. (2003) [17] & $\begin{array}{l}\text { Pull-down } \\
\text { EMSA }\end{array}$ & $\begin{array}{l}50 \mathrm{mM} \text { Tris- } \mathrm{HCl}, \mathrm{pH} \text { 7.0, } 2 \mathrm{mM} \mathrm{MgCl}_{2}, 150 \mathrm{mM} \mathrm{NaCl}, 1 \mathrm{mM} \text { DTT, } 0.25 \mathrm{mg} / \mathrm{mL} \\
\text { E.coli tRNA, } 0.25 \mathrm{mg} / \mathrm{mL} \text { BSA }\end{array}$ \\
\hline Bechara et al. (2006) [61] & EMSA & $\begin{array}{l}50 \mathrm{mM} \text { Tris- } \mathrm{HCl} \mathrm{pH} \mathrm{7.4,1} \mathrm{mM} \mathrm{MgCl}, 1 \mathrm{mM} \text { EDTA, } 150 \mathrm{mM} \mathrm{KCl}, 1 \mathrm{mM} \mathrm{DTT} \text {, } \\
0.25 \mathrm{mg} / \mathrm{mL} \text { of E.coli tRNA, } 0.01 \% \text { BSA, } 8 \text { U of RNasin }\end{array}$ \\
\hline Didiot et al. (2008) [54] & EMSA & $\begin{array}{l}50 \mathrm{mM} \text { Tris- } \mathrm{HCl} \mathrm{pH} \text { 7.4, } 1 \mathrm{mM} \mathrm{MgCl}, 1 \mathrm{mM} \text { EDTA, } 150 \mathrm{mM} \mathrm{KCl}, 1 \mathrm{mM} \text { DTT, } \\
0.25 \mathrm{mg} / \mathrm{mL} \text { of } E \text {. coli tRNA, } 0.01 \% \text { BSA, } 8 \mathrm{U} \text { of RNasin }\end{array}$ \\
\hline Zalfa et al. (2003) [36] & EMSA & $\begin{array}{l}10 \mathrm{mM} \text { HEPES pH 7.9, } 3 \mathrm{mM} \mathrm{MgCl} 2,10 \mathrm{mM} \text { DTT, } 100 \mathrm{mM} \mathrm{KCl}, 750 \mathrm{mM} \mathrm{NaCl}, 5 \% \\
\text { glycerol, } 7 \mathrm{mM} \beta \text {-Mercaptoethanol, } 1 \mathrm{mg} / \mathrm{mL} \text { Albumin, } 1.3 \mathrm{mg} / \mathrm{mL} \text { Heparin }\end{array}$ \\
\hline Zalfa et al. (2005) [40] & EMSA & $\begin{array}{l}20 \mathrm{mM} \text { HEPES-KOH, pH 7.6, } 5 \mathrm{mM} \mathrm{MgCl}_{2}, 300 \mathrm{mM} \mathrm{KCl,} 2 \mathrm{mM} \text { DTT, } 5 \% \text { glycerol, } \\
\text { and } 500 \mathrm{ng} \text { of total yeast tRNA or } 20 \mu \mathrm{g} \text { of heparin. }\end{array}$ \\
\hline Darnell et al. (2001) [22] & Filter-Binding & $10 \mathrm{mM}$ Tris-OAc pH 7.7, $200 \mathrm{mM} \mathrm{KOAc,} 5 \mathrm{mM} \mathrm{MgOAc}_{2}$ \\
\hline Darnell et al. (2005) [30] & Filter-Binding & $\begin{array}{l}50 \mathrm{mM} \text { Tris-OAc at } \mathrm{pH} \text { 7.7, } 50 \mathrm{mM} \text { KOAc, } 10 \mathrm{mM} \text { DTT, } 5 \mathrm{mM} \mathrm{Mg}(\mathrm{OAc})_{2}, 30 \mu \mathrm{g} / \mathrm{mL} \\
\text { tRNA }\end{array}$ \\
\hline Gabus et al. (2004) [42] & EMSA & $20 \mathrm{mM}$ Tris- $\mathrm{HCl} \mathrm{pH}$ 7.5, $30 \mathrm{mM} \mathrm{NaCl}, 0.2 \mathrm{mM} \mathrm{MgCl}_{2}, 5 \mathrm{mM}$ DTT, $10 \mu \mathrm{M} \mathrm{ZnCl}_{2}$ \\
\hline $\begin{array}{l}\text { Laggerbauer et al. (2001) } \\
\text { [16] }\end{array}$ & Pull-down & PBS, 0.02\% IGEPAL, 1\% BSA \\
\hline Siomi et al. (1993) [15] & Pulldown & $10 \mathrm{mM}$ Tris- $\mathrm{HCl} \mathrm{pH} 7.4,2.5 \mathrm{mM} \mathrm{MgCl} 2,0.5 \%$ Triton X-100, $100-1000 \mathrm{mM} \mathrm{NaCl}$ \\
\hline Stetler et al. (2005) [56] & Pulldown & $\begin{array}{l}2 \mathrm{M} \text { KOAc, } 100 \mathrm{mM} \text { Tris-OAc pH } 7.7 \text { and } 50 \mathrm{mM} \mathrm{MgOAc}_{2}, 1 \mu \mathrm{L} \text { of yeast tRNA, } 1 \mu \mathrm{L} \\
\text { of RNAsin }\end{array}$ \\
\hline $\begin{array}{l}\text { Menon and Mihailescu } \\
(2007)[62]\end{array}$ & EMSA & $50 \mathrm{mM}$ Tris- $\mathrm{HCl} \mathrm{pH}$ 7.5, $150 \mathrm{mM} \mathrm{NaCl}$ and protease inhibitors \\
\hline Fahling et al. (2009) [20] & EMSA & $\begin{array}{l}10 \mathrm{mM} \text { Hepes } \mathrm{pH} \text { 7.2, } 3 \mathrm{mM} \mathrm{MgCl}_{2}, 5 \% \text { glycerol, } 1 \mathrm{mM} \text { DTT, } 150 \mathrm{mM} \mathrm{KCl}, 2 \mathrm{U} / \mu \mathrm{L} \\
\text { RNaseOUT, } 0.5 \mu \mathrm{g} / \mu \mathrm{L} \text { rabbit rRNA }\end{array}$ \\
\hline Zou et al. (2008) [63] & AGESA & $20 \mathrm{mM}$ Tris- $\mathrm{HCl} \mathrm{pH} 7.2,150 \mathrm{mM} \mathrm{NaCl}$ \\
\hline Iacoangeli et al. (2008) [47] & EMSA & $\begin{array}{l}50 \mathrm{mM} \text { Tris- } \mathrm{HCl} \mathrm{pH} \text { 7.6, } 150 \mathrm{mM} \mathrm{KCl}, 1 \mathrm{mM} \mathrm{MgCl}_{2}, 1 \mathrm{mM} \text { EDTA, } 1 \mathrm{mM} \text { DTT, } \\
0.2 \mathrm{U} / \mu \mathrm{L} \\
\text { RNase inhibitor, } 100 \mathrm{ng} / \mu \mathrm{L} \text { total yeast } \mathrm{tRNA} \text {, and } 100 \mathrm{ng} / \mu \mathrm{L} \text { BSA }\end{array}$ \\
\hline
\end{tabular}

Sets of binding conditions are grouped by the different laboratories that used them. Each set of conditions is differentiated from the next by a dotted line. In some instances the same group used multiple sets of binding conditions in multiple publications.

and protein preparations form the basis for the divergent results obtained for the FMRP BC1 RNA interaction [59, 60].

We chose to examine heretofore unstudied aspects of FMRP's interaction with BC1 RNA-using affinity capture, one of the older techniques used in FMRP RNA binding studies. We next sought a basic buffer to use. In several previous publications, we have used a buffer described by Schaeffer et al. [26], which used physiological saline [17, 41, 47], Table 1. However, this buffer contains tRNA to reduce nonspecific binding, and as two publications demonstrate that FMRP can interact with tRNA [42, 47], we first determined whether specific binding between FMRP and RNA could be observed without the addition of tRNA. As shown in Figure 1 (upper panel), in the presence of physiological salt and in the absence of RNA, ${ }^{35}$ S-FMRP produced by in vitro translation in rabbit reticulocyte lysate (RRL) nonspecifically bound to the avidin affinity column; however, addition of increasing amounts of $\mathrm{NaCl}$ decreased this nonspecific interaction so that at $125 \mathrm{mM} \mathrm{NaCl}$ the amount of bound FMRP was between 5\%-10\% of the total. As expected, tRNA also blocked the association of full-length FMRP to the avidin column, Figure 1 (lower panel). Thus, 


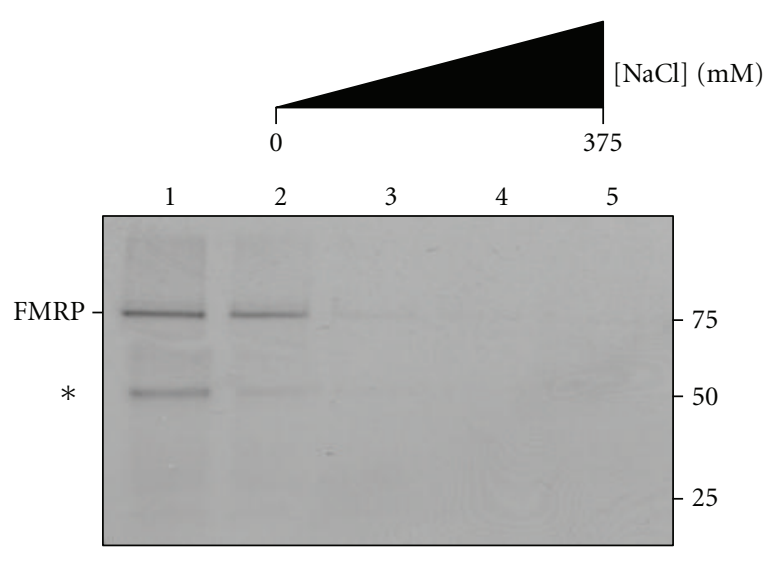

(a)

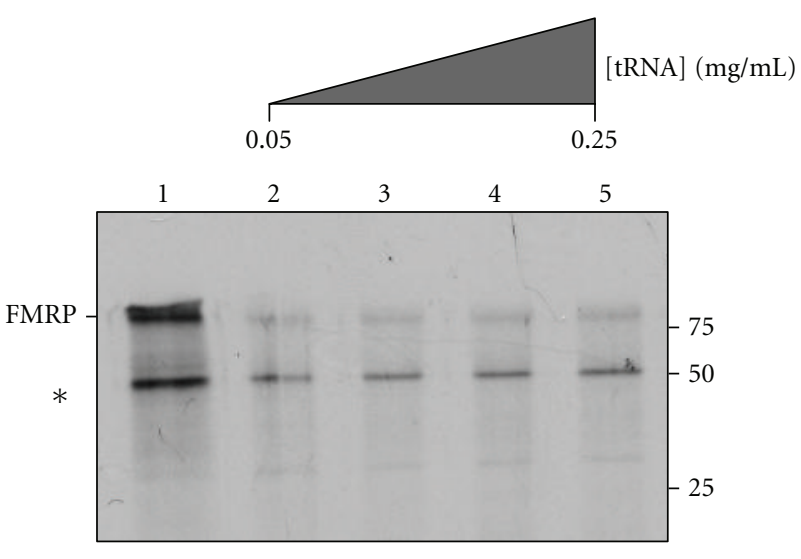

(b)

FIGURE 1: $\mathrm{NaCl}$ blocks nonspecific binding of FMRP with avidin. (a) ${ }^{35} \mathrm{~S}$-FMRP was bound to SoftLink resin in $1 \mathrm{x}$ Schaeffer binding buffer supplemented with $0 \mathrm{mM}, 125 \mathrm{mM}, 250 \mathrm{mM}$ and $375 \mathrm{mM} \mathrm{NaCl}$, lanes 2-5, respectively. Bound ${ }^{35} \mathrm{~S}$-FMRP was recovered, resolved by SDSPAGE and subject to autoradiography. Lane 1 shows the amount of ${ }^{35} \mathrm{~S}$-FMRP input into the assay. (b) ${ }^{35} \mathrm{~S}$-FMRP was bound to SoftLink resin in $1 \mathrm{x}$ Schaeffer binding buffer supplemented with $0.05 \mathrm{mg} / \mathrm{mL}, 0.1 \mathrm{mg} / \mathrm{mL}, 0.15 \mathrm{mg} / \mathrm{mL}$, and $0.25 \mathrm{mg} / \mathrm{mL}$ tRNA, lanes $2-5$, respectively. Bound ${ }^{35}$ S-FMRP was recovered, resolved by SDS-PAGE and subject to autoradiography. Lane 1 shows the amount of ${ }^{35}$ S-FMRP input into the assay. The asterisk marks a ${ }^{35} \mathrm{~S}$-truncation product produced by transcription/translation.

Schaeffer buffer supplemented with $125 \mathrm{mM} \mathrm{NaCl}$ blocks the non-specific interaction of FMRP with the affinity matrix as effectively as Schaeffer buffer supplemented with tRNA.

\subsection{Prior Annealing of BC1 RNA Enhances Its Interaction} with FMRP. Having established this basic set of conditions, we applied them to study the FMRP BC1 RNA interaction. The weak binding between FMRP and BC1 RNA that occurs in protein excess [36] suggested that the protein might be surveying the population of BC1 RNA conformers and interacting with a particular one. As BC1 RNA is known to form higher order structure [45], we performed a simple experiment to perturb the conformer population that would test this hypothesis. BC1 RNA was transcribed in vitro and purified by salt and alcohol precipitation; then, it was either heated briefly or left untreated. Each RNA (annealed and unannealed, resp.) was then was titrated with a constant amount of ${ }^{35} \mathrm{~S}$-FMRP, and the binding was assessed by affinity capture. Under the conditions used, unannealed BC1 RNA bound extremely weakly at all concentrations examined, in concert with previous obtained results $[41,64]$. On the other hand, annealed BC1 RNA exhibited stronger binding to FMRP over the range of concentrations examined, Figures 2(a) and 2(b).

To index the above results to a known standard, the interaction between eEF-1A mRNA and FMRP was also measured in parallel. Previous work had shown that this RNA binds strongly to FMRP, without prior annealing [17, 41]. As expected, the FMRP eEF-1A mRNA interaction was much stronger than the FMRP BC1 RNA interaction, Figure 2(c). In fact, with the same amount of ${ }^{35} \mathrm{~S}$-FMRP, unannealed eEF-1A mRNA evinced saturable binding at $90 \mathrm{nM}$ RNA, while it took 100-fold more annealed BC1 RNA to achieve comparable binding; see Figure 2(d).
To determine whether annealing affected the interaction of FMRP with eEF-1A mRNA, binding to annealed and unannealed forms of the message was assessed using a subsaturating concentration of eEF-1A RNA. As shown in Figure 2(e), binding of eEF-1A mRNA to ${ }^{35} \mathrm{~S}-\mathrm{FMRP}$ was not markedly affected by annealing.

3.3. Annealing Alters the Structure of BC1 RNA. The above data implied that the conformer populations of annealed and unannealed BC1 RNA differ. To determine whether this was so, the annealed and unannealed BC1 RNAs used in Figure 2 were treated with RNases whose cleavage depends on known RNA structural features and the products were resolved on nondenaturing agarose gels. In the absence of treatment, both RNAs displayed a major band as well as a less prominent, slower migrating band, Figure 3(b). These data indicate that annealed BC1 RNA and unannealed BC1 RNA contained multiple conformers. Interestingly, in the presence of RNase A, which preferentially cleaves at single-stranded $\mathrm{C}$ and $\mathrm{U}$ residues, both annealed and unannealed BC1 RNA behaved nearly identically and were completely degraded by all but the lowest amount of the enzyme. However, when the RNAs were treated with a range of concentrations of RNase V1 (0.01-1 units), which cleaves base-paired nucleotides, the unannealed form was refractory to cleavage, while the annealed form was sensitive toward cleavage at the highest amount, Figure 3(c) (upper panel). Increasing the amount of RNase V1 recapitulated the sensitivity of annealed BC1 RNA, Figure 3(c) (lower panel); however, it also demonstrated that a fraction of unannealed BC1 RNA also contained RNase V1-sensitive stable duplex RNA. To determine whether the unique BC1 RNA conformer(s) produced by annealing could be stabilized by $\mathrm{Mg}^{+2}$ the annealing reaction was also carried out in the presence of $2 \mathrm{mMMgCl}_{2}$. The results indicated that the magnesium did not alter the distribution of $\mathrm{BC} 1$ 


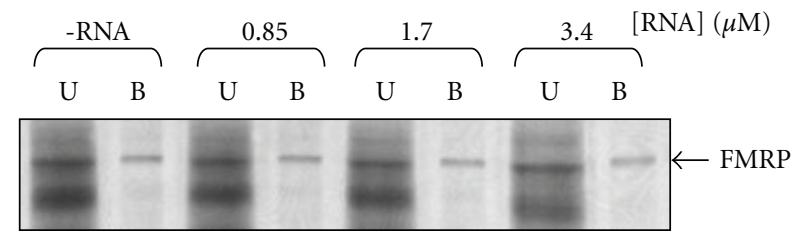

(a) BC1 RNA unannealed

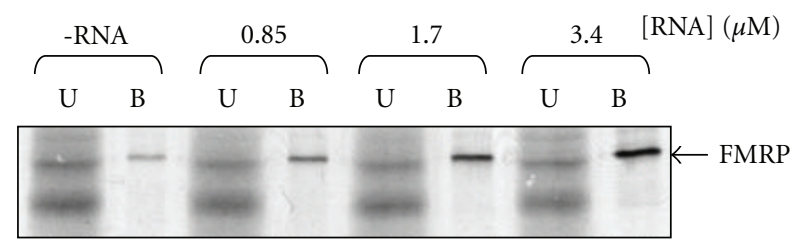

(b) BC1 RNA annealed

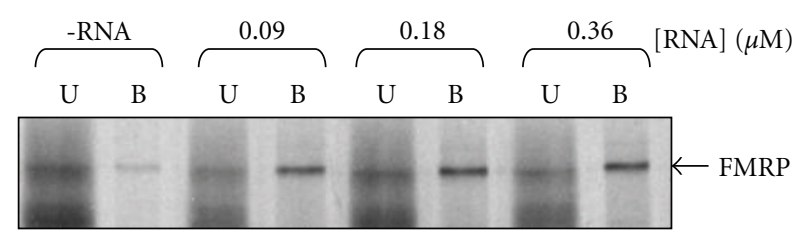

(c) EF-1A RNA unannealed

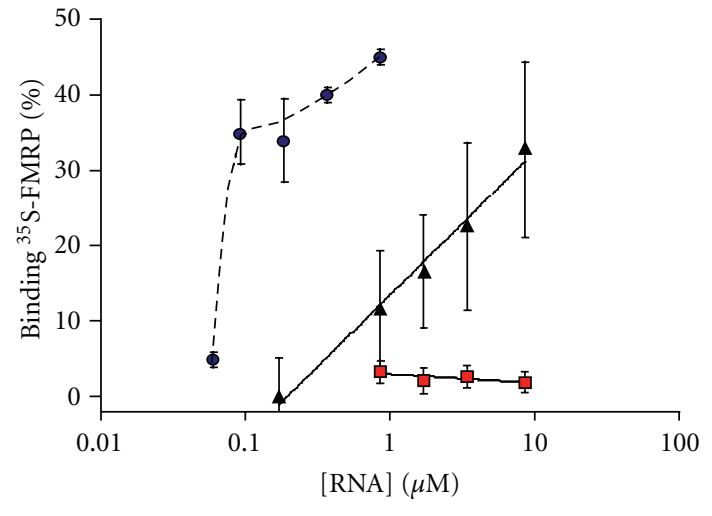

$\underset{\rightarrow-\text { BC1-annealed }}{\rightarrow \text { BC1-unannealed }}$

- - EF-1A unannealed

(d)

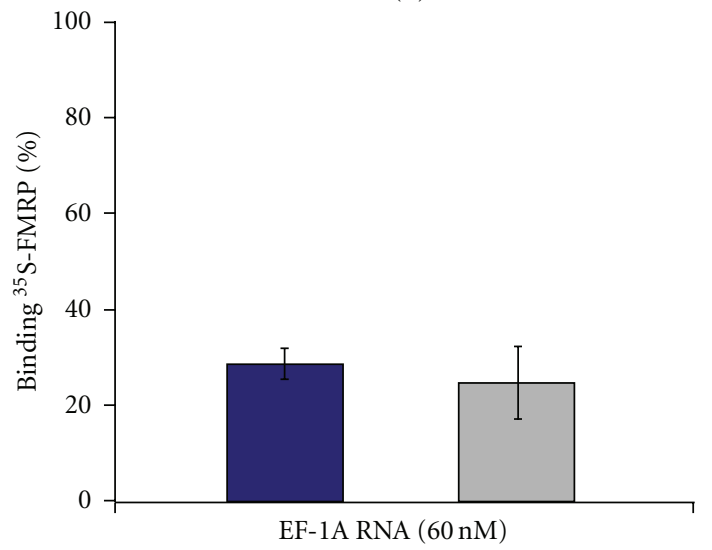

Unannealed

$\square$ Annealed

(e)

FIGURE 2: FMRP interacts weakly with annealed BC1 RNA. Equal amounts of ${ }^{35}$ S-FMRP was titrated with various amounts of (a) unannealed biotinylated-BC1 RNA, (b) annealed biotinylated-BC1 RNA, and (c) unannealed biotinylated-eEF-1A RNA, as indicated. Bound (B) and unbound (U) ${ }^{35}$ S-FMRP was recovered, resolved by SDS-PAGE and subject to autoradiography. Nonspecific binding to the SoftLink avidin resin is shown in the -RNA lanes. (d) Graphical analysis of the above data for 4 reactions per concentration. (e) Binding of annealed or unannealed eEF1A RNA $(60 \mathrm{nM})$ to ${ }^{35} \mathrm{~S}$-FMRP. The percent binding corrected for background of 4 reactions per RNA type is plotted $(P=.45$ by ANOVA).

RNA conformer(s) or affect their resistance to RNase V1 (not shown).

These data unequivocally demonstrate that the conformer populations of annealed and unannealed BC1 RNA differ, and this difference is due to an increase in the amount of stable RNA duplexes in the annealed RNA. Moreover, the data support the hypothesis that the binding between FMRP and annealed BC1 RNA results from a unique conformer that is absent from the unannealed BC1 RNA conformer population.

\subsection{Functional Dissection of the FMRP BC1 RNA Interaction.} BC1 RNA contains several distinct higher order structural elements. Its $5^{\prime}$ end contains two cis-acting spatial targeting elements, DTE1 and DTE2 [45]. The former is required for somatic export of BC1 RNA into dendrites, while the latter specifies long-range distal delivery and is mediated by a prominent GA-type kink turn (KT) motif in the apical region of the $5^{\prime} \mathrm{BC} 1$ domain [45]. The $3^{\prime} 60$ bases of BC1 RNA contains an abbreviated A-rich region and a $3^{\prime}$-terminal stem-loop structure [65] that has been shown to bind synergistically to the eucaryotic initiation factor $4 \mathrm{~A}$ (eIF4A) and the polyadenylation binding protein (PABP) [41]. To further probe this interaction, BC1 RNA was functionally dissected, and these two elements were examined individually. As shown in Figure 4(a), RNase VI treatment of the $5^{\prime} 75$ bases of $\mathrm{BC} 1$ RNA recapitulated the results of full-length $\mathrm{BC} 1 \mathrm{RNA}$ indicating that it forms a stable secondary structure in the absence of the $3^{\prime}$ end. This agrees with modeling studies using the Zuker M-fold 


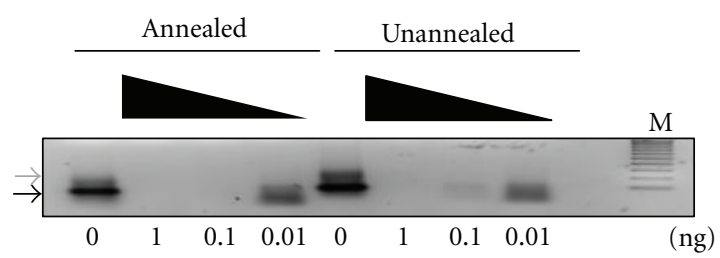

(b) RNAse A

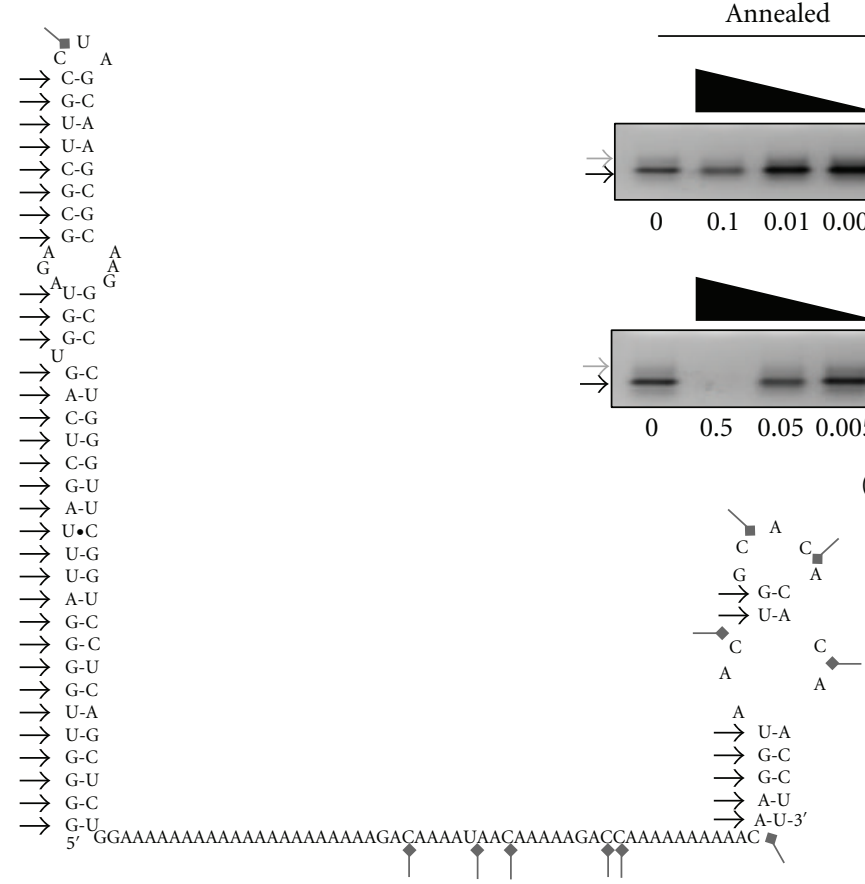

(a)

Figure 3: Annealed BC1 RNA and unannealed BC1 RNA differ structurally. (a) Secondary structure model of BC1 RNA from M-fold. Black arrows indicate potential RNase VI cleavage sites (both sides of the stem); gray arrows mark potential RNase A cleavage sites. (b) Serial treatment of annealed and unannealed full-length BC1 RNA with RNase A starting at $1 \mathrm{ng}$ as indicated. (c) Ten-fold serial treatment of annealed and unannealed full-length BC1 RNA with RNase VI starting with 0.1 units/ $\mu \mathrm{L}$ (upper panel), or 0.5 units $/ \mu \mathrm{L}$ (lower panel) as indicated. RNA was visualized by ethidium bromide staining. Arrows mark the major conformers that can be resolved in this system. Lane M shows 100 bp molecular weight markers.

algorithm, which show that the first 75 bases of BC1 RNA fold identically to that portion of the full-length molecule, Figure 4(b). On the other hand, annealing had no effect on the sensitivity of the $3^{\prime} 60$ bases of BC1 RNA towards RNase VI, Figure 5. Thus, these data demonstrate that the difference in the conformer populations of annealed and unannealed BC1 RNA most likely arise from alterations in the $5^{\prime}$ end of the molecule.

We next examined whether FMRP preferentially bound either of the dissected RNAs. Therefore, ${ }^{35} \mathrm{~S}$-FMRP was incubated with $2 \mu \mathrm{M}$ annealed versions of each RNA; binding was subsequently assessed by affinity capture and compared to that of annealed full-length BC1 RNA. We found that the $5^{\prime} 75$ bases of BC1 RNA bound slightly less, than full-length BC1 RNA, Figure 6(a); however, the difference did not rise to the level of statistical significance $(P=.15$, ANOVA). Truncation of this RNA by a 15 base deletion at its $3^{\prime}$ end further decreased binding ( $P=.08$, ANOVA). Significantly, this 60 base RNA is not expected to recapitulate the folding of the first 60 bases of full-length BC1 RNA, Figure 6(b). On the other hand, the 3' 60 bases of BC1 RNA evinced no evidence of binding, Figure 6(a). These data suggest that the major determinant that FMRP recognizes in annealed BC1 RNA is the hairpin structure of the $5^{\prime}$ end. To test this further, we also conducted binding studies using an 85 base RNA harboring the HIV1 TAR hairpin, Figure 6(c). The results show that this RNA binds with the same affinity as annealed full-length $\mathrm{BC} 1$ RNA.

3.5. Specificity and Requirements of the FMRP BC1 RNA Interaction. Different preparations or sources of FMRP has been posited as a potential explanation for the divergent $\mathrm{BC} 1$ RNA-binding data obtained by different laboratories $[59,60]$ and a likely cause of such differences is in the posttranslation modifications that occur in each. To begin to address this question, we examined whether differences in posttranslational arginine methylation could alter the binding affinity of annealed BC1 RNA and FMRP. Specifically, we compared the 


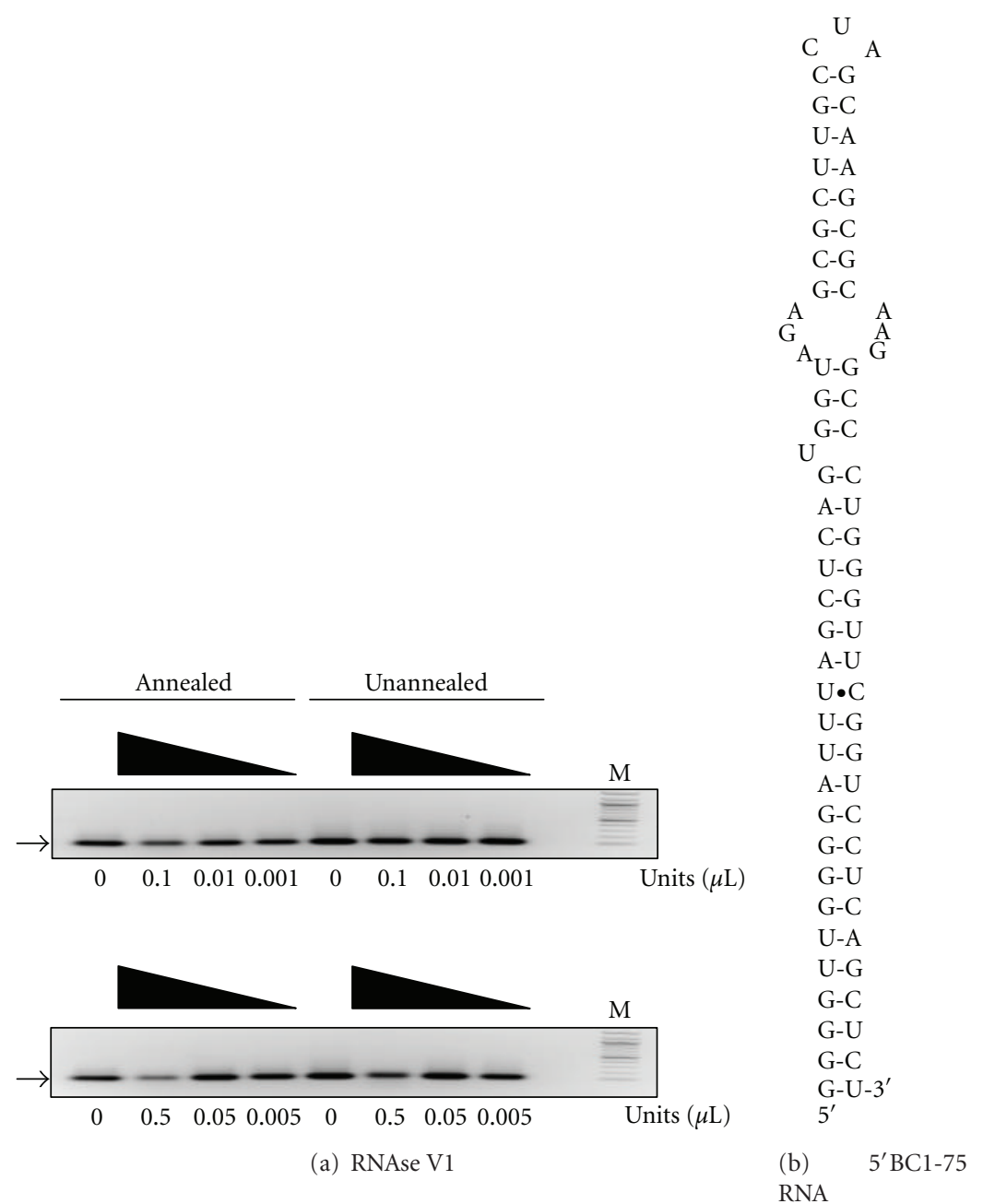

Figure 4: Functional dissection of structural elements in the 5' end of BC1 RNA. (a) Ten-fold serial treatment of annealed and unannealed 5'BC1-75 RNA with RNase VI starting at 0.1 units $/ \mu \mathrm{L}$ (upper panel) or 0.5 units/ $\mu \mathrm{L}$ (lower panel). Arrow marks the major conformer. Lane M shows 100 bp molecular weight markers. (b) Secondary structure model of 5'BC1-75 RNA from M-fold.
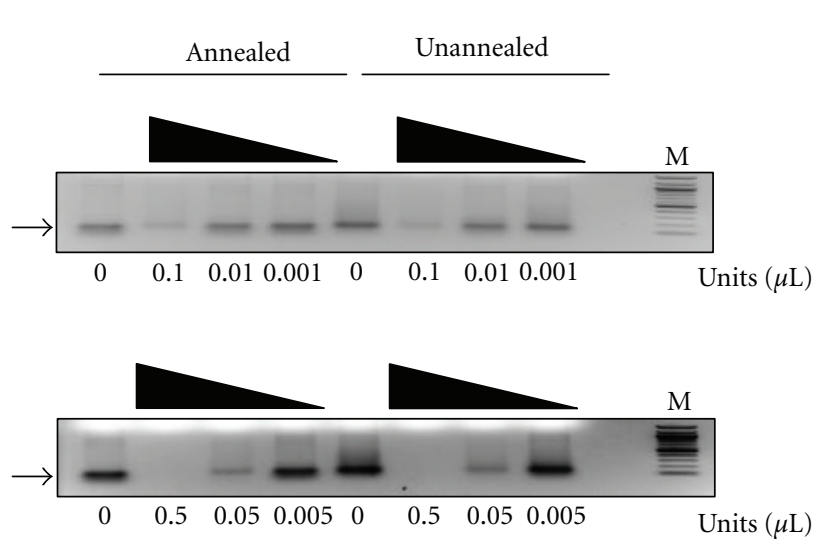

(a) RNAse V1

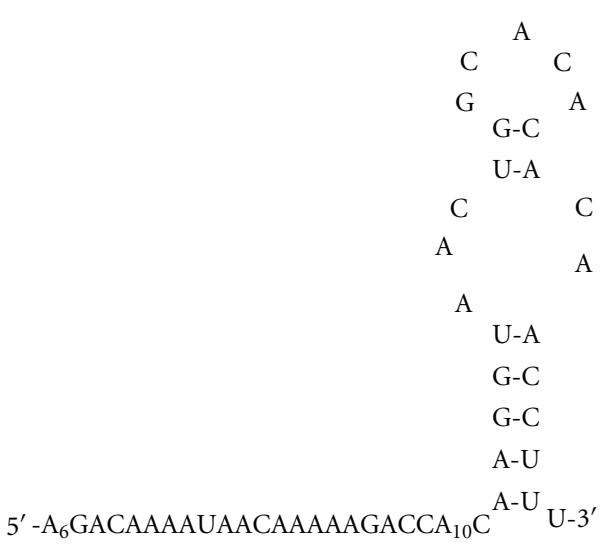

(b) 3'BC1-S RNA

FIgURE 5: Functional dissection of structural elements in the $3^{\prime}$ end of BC1 RNA. (a) Ten-fold serial treatment of annealed and unannealed 3'BC1-60 RNA with RNase VI starting at 0.1 units/ $\mu \mathrm{L}$ (upper panel) or 0.5 units/ $\mu \mathrm{L}$ (lower panel). Arrow marks the major conformer. Lane M shows 100 bp molecular weight markers. (b) Secondary structure model of 3'BC1-60 RNA from M-fold. 


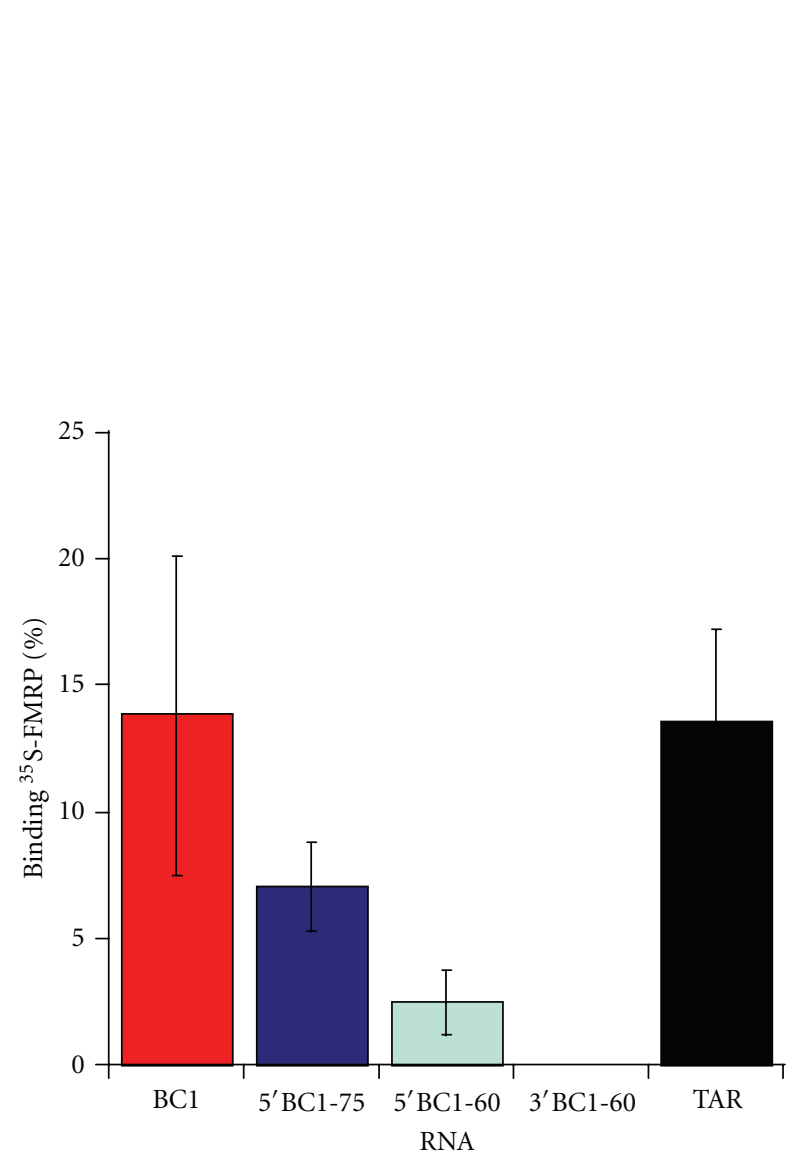

(a)

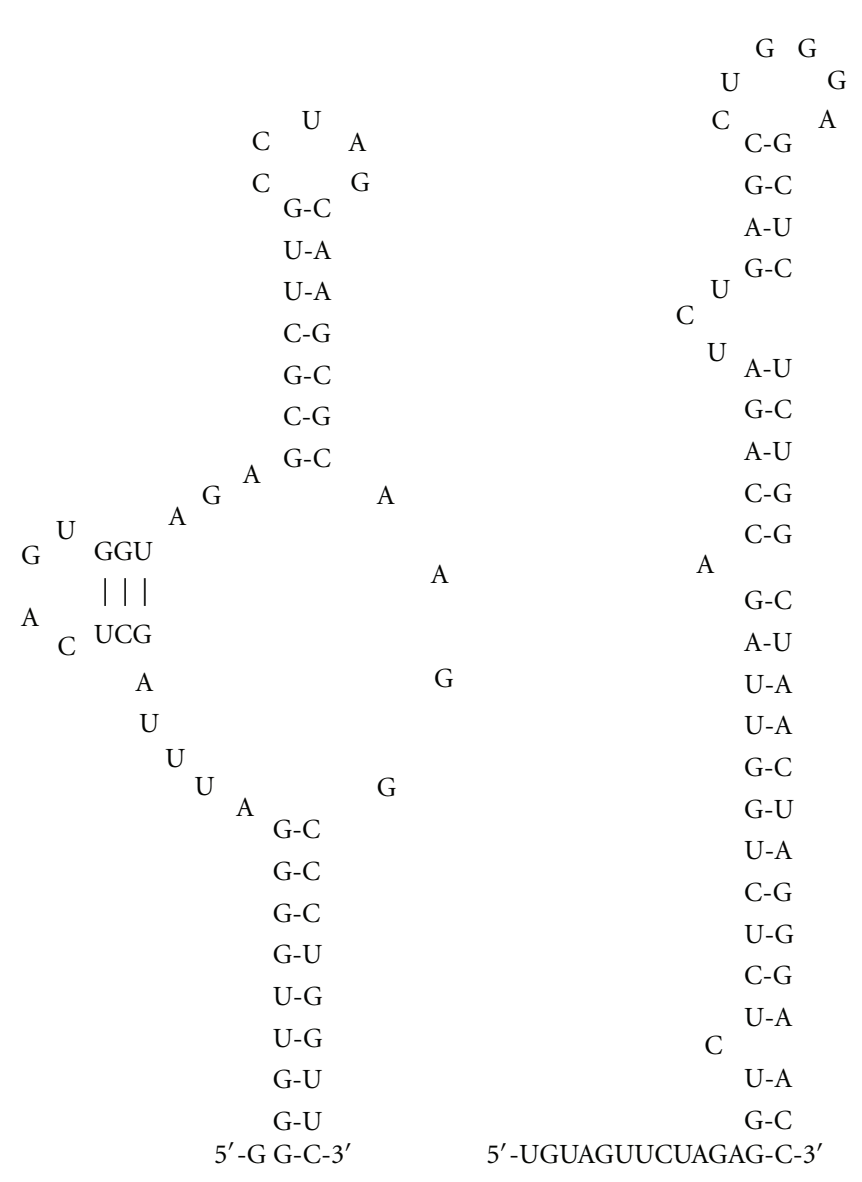

(b)

(c)

FIgURE 6: Interaction of FMRP with the $5^{\prime}$ and $3^{\prime}$ ends of BC1 RNA. (a) ${ }^{35}$ S-FMRP was incubated with $2 \mu$ M annealed full-length BC1 RNA, or annealed versions of the first $75 \mathrm{~b}$ of BC1 RNA (5'BC1-75), the first $60 \mathrm{~b}$ of BC1 RNA (5'BC1-60) the last $60 \mathrm{~b}$ of BC1 RNA (3'BC1-60) and an $85 \mathrm{~b}$ transcript containing the HIV1 TAR hairpin. The percent binding corrected for background of 6 reactions per protein is plotted. (b) Secondary structure model of 5'BC1-60 RNA from M-fold. (c) Secondary structure model of the HIV1 TAR RNA from M-fold; the 27 b leader sequence has no effect upon the folding.

ability of full-length FMRP and the ability of an alternatively spliced variant $\mathrm{FMRP}_{\mathrm{Ex} 15 \mathrm{c}}$ to bind $2 \mu \mathrm{M}$ annealed BC1 RNA. Previous studies showed that full-length FMRP is readily methylated in its RG-rich region, while $\mathrm{FMRP}_{15}$, which lacks 25 amino acids upstream of the RG-rich region, is refractory to arginine methylation [66]. Figure 7(a) shows that binding of annealed BC1 RNA to $\mathrm{FMRP}_{15 c}$ was less than it was to full-length FMRP, but the difference did not rise to statistical significance.

We next examined whether the binding between annealed BC1 RNA and FMRP was unique. As an initial indicator, $2 \mu \mathrm{M}$ annealed BC1 RNA was incubated with equimolar amounts of fragile X family members, ${ }^{35} \mathrm{~S}$-FMRP, ${ }^{35}$ S-FXR1P and ${ }^{35}$ S-FXR2P (full-length forms); subsequently, binding was assessed as previously described. As shown in Figure 7(a), both FXR1P and FXR2P bound as well as FMRP. To confirm and extend these results binding studies between annealed BC1 RNA and luciferase or eIF4A were performed. Luciferase does not contain any RNA-binding motifs and does not bind to poly (rA), poly (rG), or eEF$1 \mathrm{~A}$ mRNA, Figure 7(b). Correspondingly, we found that luciferase did not interact with annealed BC1 RNA. On the other hand, the RNA helicase, eIF4A, bound weakly annealed BC1 RNA under these conditions, Figure $7(a)$. These data indicate that in addition to FMRP annealed BC1 RNA can interact interchangeably with at least three other RNAbinding proteins.

It has been previously proposed that $\mathrm{BC} 1 \mathrm{RNA}$ interacts with the N-terminal domain (NTD) of FMRP [40]. Nevertheless, Wang et al. did not observe an interaction between unannealed BC1 RNA and a 280 amino acid NTD construct, FMRP $_{1-280}$ [41]. To complete this analysis, we also assessed the interaction of annealed BC1 RNA with $\mathrm{FMRP}_{1-280}$. As shown in Figure 7(a), annealed BC1 RNA did not bind to ${ }^{35} \mathrm{~S}_{-F M R P}{ }_{1-280}$. To determine whether ${ }^{35} \mathrm{~S}_{-} \mathrm{FMRP}_{1-280}$ lacked the ability to interact with RNA, we asked whether it could to bind to homoribopolymers. As shown in Figure 7(c), ${ }^{35} \mathrm{~S}$ $\mathrm{FMRP}_{1-280}$ was unable to bind to poly $(\mathrm{rA})$, poly $(\mathrm{rG})$, or poly(rI:rC). These data suggest that ${ }^{35}{ }^{3}-\mathrm{FMRP}_{1-280}$ does not significantly interact with ribonucleic acids under the conditions used. Interestingly, however, while a shorter NTD, that is, ${ }^{35} \mathrm{~S}-\mathrm{FMRP}_{1-204}$, was also unable to bind to annealed 


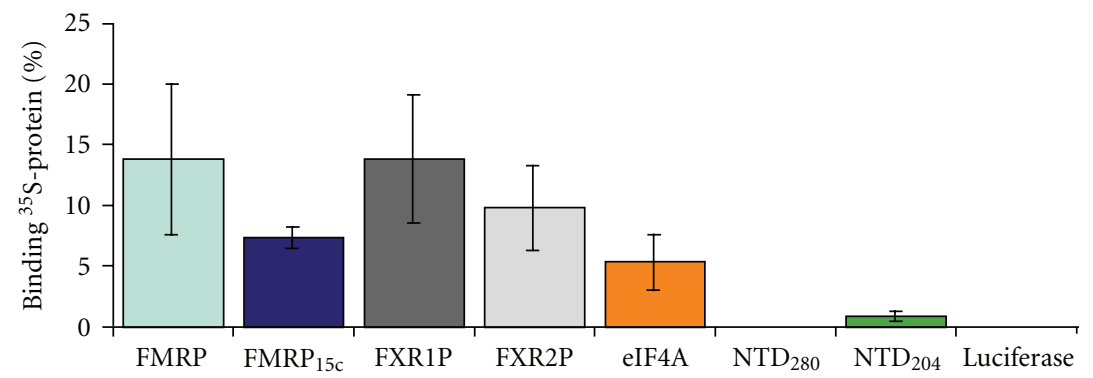

(a)
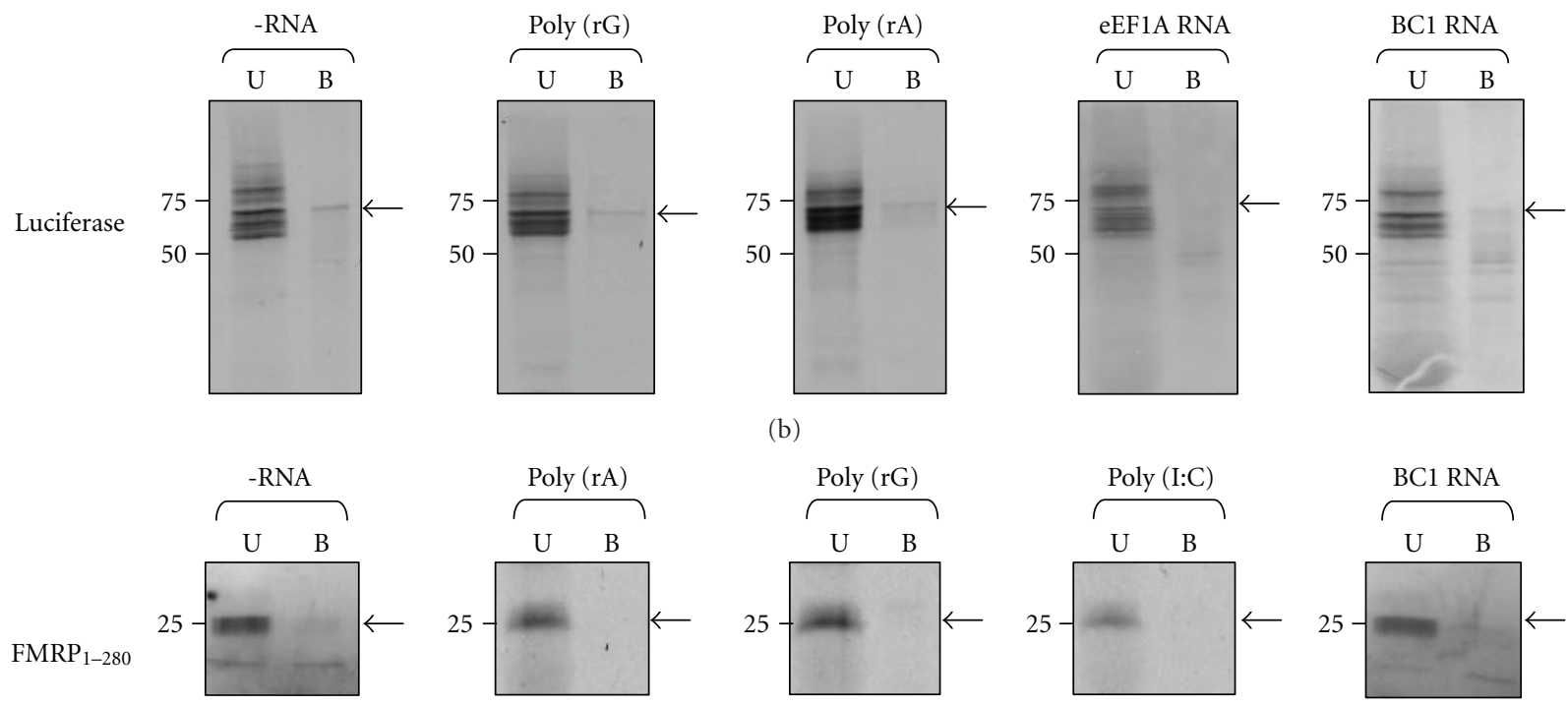

(b)
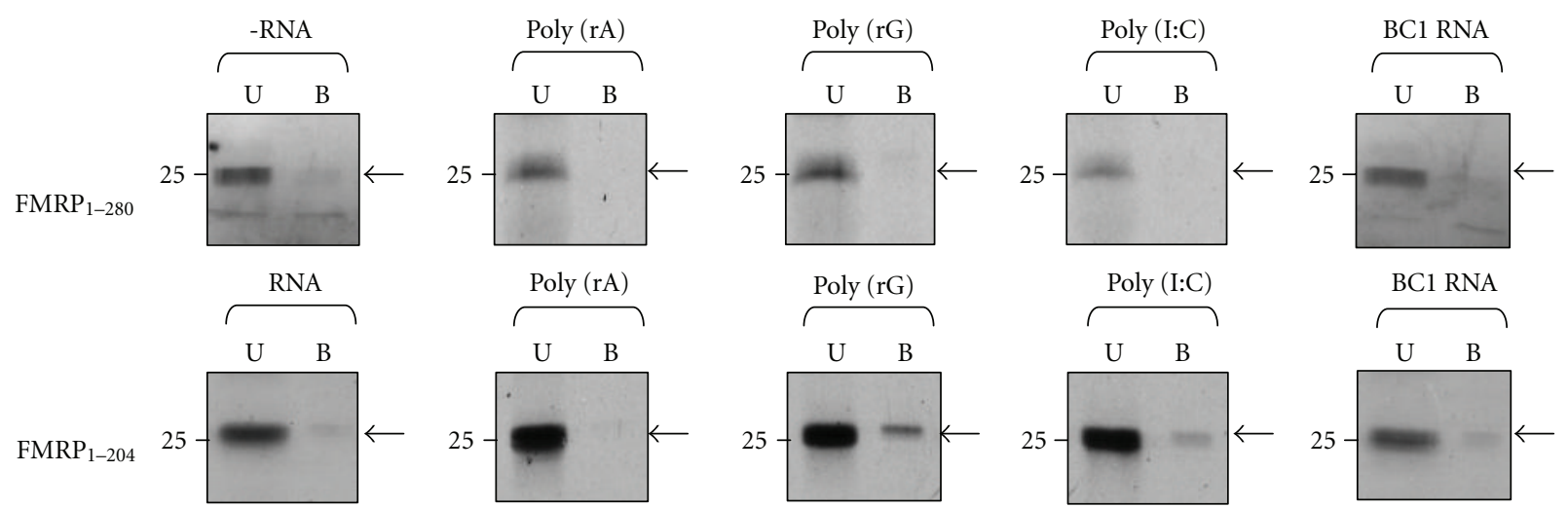

(c)

Figure 7: Annealed BC1 RNA binds pleiotropically to the FXRPs. (a) Equimolar amounts of ${ }^{35}$ S-FMRP, ${ }^{35}$ S-FMRP $15 c,{ }^{35}$ S-FXR1P, ${ }^{35}$ S-FXR2P, ${ }^{35} \mathrm{~S}$-eIF4A, ${ }^{35} \mathrm{~S}-\mathrm{FMRP}_{280},{ }^{35} \mathrm{~S}-\mathrm{FMRP}_{204}$, and ${ }^{35} \mathrm{~S}$-Luciferase were incubated with $2 \mu \mathrm{M}$ annealed BC1 RNA. The percent binding corrected for background of 6 reactions per protein is plotted. The relative levels of FMRP and FMRP ${ }_{15 c}$, FMRP and FXR1P and FMRP and FXR2P were not significantly different $(P=.17, P=.67$ and $P=.27$, resp., ANOVA). However, the relative levels of FMRP and eIF4A and FMRP and $\mathrm{NTD}_{204}$ were significantly different $(P=.038$ and $P=.007$, resp., ANOVA). Since no binding above background was observed for NTD 280 and Luciferase relative differences were not assessed. (b) Pull-down assays between ${ }^{35}$ S-luciferase and poly (rG), poly (rA), eEF1A RNA $(90 \mathrm{nM})$ and annealed BC1 RNA $(5 \mu \mathrm{M})$ showing the unbound (U) and bound (B) fractions. Binding in the absence of RNA is shown for the negative control. (c) Pull-down assays between ${ }^{35} \mathrm{~S}_{-} \mathrm{NTD}_{280}$ or ${ }^{35} \mathrm{~S}-\mathrm{NTD}_{204}$ and poly (rG), poly (rA), poly (rI : rC) and annealed BC1 RNA $(5 \mu \mathrm{M})$ showing the unbound $(\mathrm{U})$ and bound (B) fractions. Binding in the absence of RNA is shown for the negative control.

BC1 RNA, Figure 7(a), it was able to bind specifically to poly $(\mathrm{rG})$ and to a lesser extent, poly(rI:rC), Figure 7(c). Thus, annealed BC1 RNA does not interact significantly with the $204 \mathrm{~N}$-terminal residues of FMRP.

\section{Conclusions}

Disparate data obtained using electrophoretic mobility shift assays have been published concerning the binding of FMRP to BC1 RNA [36, 40, 47]. To investigate this discrepancy, we turned to an affinity capture assay to measure RNA binding to FMRP under the assumption that the results from different assays should converge to produce a common result. This particular assay was first described by Boehlens et al. and applied to the interactions of FMRP and nucleic acids by Ashley et al. [51, 67]. Here, we demonstrate that in $150 \mathrm{mM} \mathrm{KCl}$ and $125 \mathrm{mM} \mathrm{NaCl}$, the assay has a dynamic range of RNA binding of at least two logs. Thus, it is able to distinguish high affinity binding from low affinity binding. 
We specifically developed these assay conditions, which do not utilize tRNA as a general nonspecific binding competitor, because it had previously been demonstrated that both tRNA and BC1 RNA bind to FMRP in a low salt buffer with nearly identical dissociation constants $\left(\mathrm{K}_{\mathrm{d}} \mathrm{s}\right)[42]$, and because tRNA was shown to directly displace BC1 RNA from FMRP [47]. Thus, tRNA, while admittedly effective, may not be the best blocking reagent for examining FMRP's interaction with BC1 RNA. On the other hand, FMRP's association with polyribosomes [37, 38], translationally repressed ribosomes within neuronal granules [68], and its function in translational regulation $[17,19,27]$ indicates that it operates in an environment with a relatively high local concentration of tRNA, which would ensure a direct competition with BC1 RNA. Indeed, previously published immunoprecipitation experiments, which are carried out in the presence of a large excess of tRNA (both added and from the endogenous tRNA present during cell lysis) and which fail to find BC1 RNA among the precipitated transcripts are entirely consistent with a direct competition between BC1 RNA and tRNA [47]. Here, we demonstrate that BC1 RNA produced simply by in vitro transcription does not interact with FMRP even in the absence of tRNA, confirming our previous results using different assays and different binding conditions [41]. Nevertheless, by artificially annealing the BC1 RNA transcript, we found that binding occurred although it was at least a hundred-fold weaker than that between FMRP and eEF-1A mRNA. Previous protocols examining the interaction between BC1 RNA and FMRP have not indicated that the RNA was pretreated or annealed before binding to FMRP was initiated [36, 40, 47]; therefore, it must be assumed that it was not, and hence, this treatment is unique to this work.

To try to understand the result, we first determined whether enhanced binding due to annealing was a general feature of FMRP's interaction with RNA. A search of the current literature produced mixed results. Darnell et al., working with kissing complex RNA a small double hairpin with additional loop-loop tertiary interactions that binds to FMRP's $\mathrm{KH}_{2}$ domain, preannealed the RNA before binding was initiated [30]. Likewise, Ramos et al. and Zanotti et al. preannealed the synthetic G-rich RNA, sc1, to form G-quartets before binding to RGG box peptides $[69,70]$. Finally, Bechara et al. renatured SoSLIP RNA, a small multiple hairpin-containing RNA, before they used it in binding reactions with FMRP [19]. In contrast, longer RNAs containing U-rich motifs such as MBP mRNA [71], the FMR1 3'UTR [21], eEF-1A mRNA [17], and BMP receptor mRNA [41] do not require preannealing to bind tightly to FMRP. However, none of these studies directly compare binding between annealed and unannealed RNAs. Therefore, we examined the effect annealing eEF-1A mRNA had on its binding to FMRP. Under conditions where FMRP's interaction with unannealed eEF-1A was linearly related to the input RNA we found that preannealing the RNA had no measurable effect upon the binding. Thus, while not a general requirement for FMRP binding preannealing may be necessary for smaller RNAs whose structure is more susceptible to changes in temperature, buffer $\mathrm{pH}$, concentration and type of ions and RNA concentration [70].

We next determined whether annealed BC1 RNA was structurally altered from unannealed BC1 RNA. Indeed, we showed that the annealed form exhibited an increased susceptibility to cleavage by RNase VI. These data support the hypothesis that a particular BC1 RNA conformer; that is, one containing a unique doubled-stranded RNA structure was the true FMRP interactor. Functional dissection of BC1 RNA into either a $5^{\prime}$ ID element or a $3^{\prime}$ element demonstrated that the major determinant that FMRP binds to is located in the $5^{\prime} 75$ bases of the molecule. As FMRP also binds to tRNA and TAR RNA, these data imply that FMRP can weakly recognize hairpin-containing RNAs.

Another difference between the published FMRP BC1 RNA interaction studies was that one group used fulllength recombinant FMRP produced from baculovirus [36, 40], while the other group used full-length recombinant FMRP produced in E. coli [47]. A potential concern here is that each of these preparations may be differentially posttranslationally modified. Indeed, it is well known that FMRP is subject to posttranslational methylation of arginine residues in its $\mathrm{RG}$-rich region $[18,31]$. However, while protein arginine methyltransferases are present in Spodoptera frugiperda [72], the host cells used in baculovirus FMRP production [40], they are absent from E. coli $[73,74]$. Thus, it is possible that the presence or absence of methyl-arginine residues might directly or indirectly affect an interaction between FMRP and BC1 RNA. In the present work, we opted to produce full-length FMRP in rabbit reticulocyte lysates (RRL), which generates partially methylated FMRP [66]. Again, we assumed that posttranslational modifications arising from source differences could be a modulating but not the determining factor in a putative FMRP BC1 RNA interaction. Precedence for this assumption may be seen in the work of Stetler et al. who showed that methylating FMRP decreased, but did not abrogate, the direct binding of two G-quartet RNAs to FMRP's RG-rich region [56]. Consistent with the work using E. coli-purified FMRP [47] and with the work of Wang et al. who used unmethylated FMRP produced in cell-free wheat germ lysates to examine BC1 RNA binding [41], we observed minimal interactions between RRL-produced FMRP and unannealed BC1 RNA. Thus, methylating FMRP's arginine residues does not enhance its affinity for unannealed BC1 RNA. Furthermore, although binding between annealed BC1 RNA and the methylation refractory form of FMRP $\left(\mathrm{FMRP}_{15 \mathrm{c}}\right)$ was reduced compared to methylated FMRP, it was not a statistically significant reduction. Thus, methylarginine residues in FMRP's RG-rich region are not absolutely required for this interaction either.

We also probed the exclusivity of FMRP's interaction with annealed BC1 RNA. Here, we found that interactions of similar magnitude occur with fragile X paralogs FXR1P and FXR2P and to a lesser extent, eIF4A. These results demonstrate that BC1 RNA binds indiscriminately to RNAbinding proteins. Interestingly, contrasting results were recently obtained for kissing complex (kc) RNA [34], where it was shown that this RNA exclusively interacts with the 
fragile X paralogs but not with other related $\mathrm{KH}$ domaincontaining RNA-binding proteins.

As all three paralogs have highly homologous N-terminal sequences but are more divergent in their C-terminal ends [75], we inquired whether annealed BC1 RNA interacted with specific N-terminal fragments of FMRP (NTDs). We did not observe an interaction between annealed BC1 RNA and $\mathrm{FMRP}_{1-280}$, a construct comprising both $\mathrm{N}$-terminal residues and the first $\mathrm{KH}$ domain $\left(\mathrm{KH}_{1}\right)$. The results were consistent with previous work showing that this construct did not interact with unannealed BC1 RNA [41]. However, as $\mathrm{FMRP}_{1-280}$ did not interact with other nucleic acids under these conditions, we could not rule out the possibility that the protein was mis-folded although previous physical evidence suggests this is not the case [50]. Therefore, we also examined the interaction between annealed BC1 RNA and $\mathrm{FMRP}_{1-204}$, a construct that does interact with nucleic acids and is expected "to be at least partially folded and be monodisperse" under the conditions it was used [50]. Nevertheless, annealed BC1 RNA did not interact with this FMRP fragment either. Hence, the first 204 residues of FMRP, which includes two Tudor domains and an alpha helix that is essential for domain stability [76], are not required for the interaction of annealed BC1 RNA with FMRP. Using different conditions, Zalfa et al. have suggested that $\mathrm{BC} 1$ RNA binds to an NTD comprising amino acids 1-217 [40]. The additional 13 residues of this construct comprise part of another alpha helix, which stabilizes the folding of FMRP's $\mathrm{KH}_{1}$ domain [50]. While it is possible that amino acids 205217 may confer binding specificity to annealed BC1 RNA, Zalfa et al. showed that a construct comprising this alpha helix along with the $\mathrm{KH}_{1}$ domain (residues 205-280) did not interact with BC1 RNA [40]. However, additional studies using other constructs will be needed to fully address the question of which FMRP residues are necessary and sufficient for its interaction with annealed BC1 RNA.

Although we demonstrate an in vitro interaction between FMRP and BC1 RNA, its nature and its physiological significance remain elusive. For example, the structure of the unique $\mathrm{BC} 1 \mathrm{RNA}$ conformer that FMRP binds to has not been defined other than the fact that it contains doublestranded RNA and is primarily found in the $5^{\prime}$ half of the molecule. In fact, it is possible based on the rather high RNA concentrations used in the annealing reaction that FMRP may be interacting with a dimer of BC1 RNA. This would be analogous to the formation of intermolecular Gquartet RNAs such as MAP1B RNA [69]. Clearly, a more comprehensive biophysical analysis of the parameters of this interaction is needed to fully address this issue. Regardless, the ultimate significance of this observation is questionable given that the formation of this conformer does not occur at temperatures that mammalian cells can survive. Although one might postulate that a chaperone protein may be able to mitigate the temperature requirement for annealing [77, 78], it is clear that FMRP cannot be this chaperone, because it is unable convert unannealed $\mathrm{BC} 1 \mathrm{RNA}$ into a molecule that it binds under physiological conditions. Given this, our data generated using different constructs, different preparations and different methods, converge with the published work of
Iacoangeli et al. [47] to support a model in which FMRP and BC1 RNA operate independently of each other to control protein synthesis in neuronal processes.

\section{Abbreviations}

AGESA: Agarose electrophoretic mobility shift assays

BC1 RNA: Brain cytoplasmic RNA

eEF-1A: Eucaryotic elongation factor $1 \mathrm{~A}$

eIF4A: Eucaryotic initiation factor 4A

EMSA: Electrophoretic mobility shift assays

FMRP: $\quad$ Fragile $\mathrm{X}$ mental retardation protein

NTD: N-terminal domain

PABP: $\quad$ Polyadenylation binding protein

RBP: $\quad$ RNA binding protein

RRL: Rabbit reticulocyte lysate.

\section{Acknowledgments}

The authors thank Drs. Henri Tiedge, Edward Khandjian, Stefan Kindler and Jurgen Brosius for critically reading this paper. This work was supported by the New York State Research Foundation for Mental Hygiene.

\section{References}

[1] C. Bagni and W. T. Greenough, "From mRNP trafficking to spine dysmorphogenesis: the roots of fragile X syndrome," Nature Reviews Neuroscience, vol. 6, no. 5, pp. 376-387, 2005.

[2] B. Bardoni, L. Davidovic, M. Bensaid, and E. W. Khandjian, "The fragile X syndrome: exploring its molecular basis and seeking a treatment," Expert Reviews in Molecular Medicine, vol. 8, no. 8, pp. 1-16, 2006.

[3] P. Jin and S. T. Warren, "New insights into fragile X syndrome: from molecules to neurobehaviors," Trends in Biochemical Sciences, vol. 28, no. 3, pp. 152-158, 2003.

[4] W. T. O'Donnell and S. T. Warren, "A decade of molecular studies of fragile X syndrome," Annual Review of Neuroscience, vol. 25, pp. 315-338, 2002.

[5] V. Mercaldo, G. Descalzi, and M. Zhuo, "Fragile X mental retardation protein in learning-related synaptic plasticity," Molecules and Cells, vol. 28, no. 6, pp. 501-507, 2009.

[6] S. M. Till, “The developmental roles of FMRP," Biochemical Society Transactions, vol. 38, no. 2, pp. 507-510, 2010.

[7] A. Lo-Castro, E. D'Agati, and P. Curatolo, "ADHD andgenetic syndromes," Brain and Development. In press.

[8] P. Hagerman and C. E. Stafstrom, "Origins of epilepsy in fragile X syndrome," Epilepsy Currents, vol. 9, no. 4, pp. 108112, 2009.

[9] B. J. Flynn, S. M. Myers, P. J. Cera, and J. J. Mowad, "Testicular torsion in an adolescent with fragile $\mathrm{X}$ syndrome," Pediatrics, vol. 109, no. 1, p. E16, 2002.

[10] L. Chakrabarti and K. E. Davies, "Fragile X syndrome," Current Opinion in Neurology, vol. 10, no. 2, pp. 142-147, 1997.

[11] B. A. Oostra and R. Willemsen, "A fragile balance: FMR1 expression levels," Human Molecular Genetics, vol. 12, no. 2, pp. R249-R257, 2003. 
[12] P. J. Hagerman and R. J. Hagerman, "Fragile X-associated, tremor/ataxia syndrome (FXTAS)," Mental Retardation and Developmental Disabilities Research Reviews, vol. 10, no. 1, pp. 25-30, 2004.

[13] H. Tan, H. Li, and P. Jin, "RNA-mediated pathogenesis in fragile X-associated disorders," Neuroscience Letters, vol. 466, no. 2, pp. 103-108, 2009.

[14] B. A. Oostra and R. Willemsen, "FMR1: a gene with three faces," Biochimica et Biophysica Acta, vol. 1790, no. 6, pp. 467477, 2009.

[15] H. Siomi, M. C. Siomi, R. L. Nussbaum, and G. Dreyfuss, "The protein product of the fragile $\mathrm{X}$ gene, FMR1, has characteristics of an RNA-binding protein," Cell, vol. 74, no. 2, pp. 291-298, 1993.

[16] B. Laggerbauer, D. Ostareck, E.-M. Keidel, A. OstareckLederer, and U. Fischer, "Evidence that fragile X mental retardation protein is a negative regulator of translation," Human Molecular Genetics, vol. 10, no. 4, pp. 329-338, 2001.

[17] Y. J. Sung, N. Dolzhanskaya, S. L. Nolin, T. Brown, J. R. Currie, and R. B. Denman, "The fragile X mental retardation protein FMRP binds elongation factor $1 \mathrm{~A}$ mRNA and negatively regulates its translation in vivo," Journal of Biological Chemistry, vol. 278, no. 18, pp. 15669-15678, 2003.

[18] R. B. Denman, N. Dolzhanskaya, and Y. J. Sung, "Regulating a translational regulator: mechanisms cells use to control the activity of the fragile X mental retardation protein," Cellular and Molecular Life Sciences, vol. 61, no. 14, pp. 1714-1728, 2004.

[19] E. G. Bechara, M. C. Didiot, M. Melko et al., "A novel function for fragile $\mathrm{X}$ mental retardation protein in translational activation," PLoS Biology, vol. 7, no. 1, article e16, 2009.

[20] M. Fahling, R. Mrowka, A. Steege et al., "Translational regulation of the human achaete-scute homologue-1 (hASH1) by fragile $\mathrm{x}$-mental retardation protein (FMRP)," Journal of Biological Chemistry, vol. 284, no. 7, pp. 4255-4266, 2009.

[21] Y. J. Sung, J. Conti, J. R. Currie, W. T. Brown, and R. B. Denman, "RNAs that interact with the fragile $\mathrm{X}$ syndrome RNA binding protein FMRP," Biochemical and Biophysical Research Communications, vol. 275, no. 3, pp. 973-980, 2000.

[22] J. C. Darnell, K. B. Jensen, P. Jin, V. Brown, S. T. Warren, and R. B. Darnell, "Fragile X mental retardation protein targets G quartet mRNAs important for neuronal function," Cell, vol. 107, no. 4, pp. 489-499, 2001.

[23] L. Chen, S.-W. Yun, J. Seto, W. Liu, and M. Toth, "The fragile $\mathrm{X}$ mental retardation protein binds and regulates a novel class of mRNAs containing u rich target sequences," Neuroscience, vol. 120, no. 4, pp. 1005-1017, 2003.

[24] V. Brown, P. Jin, S. Ceman et al., "Microarray identification of FMRP-associated brain mRNAs and altered mRNA translational profiles in fragile X syndrome," Cell, vol. 107, no. 4, pp. 477-487, 2001.

[25] K. Y. Miyashiro, A. Beckel-Mitchener, T. P. Purk et al., "RNA cargoes associating with FMRP reveal deficits in cellular functioning in Fmr1 null mice," Neuron, vol. 37, no. 3, pp. 417-431, 2003.

[26] C. Schaeffer, B. Bardoni, J.-L. Mandel, B. Ehresmann, C. Ehresmann, and H. Moine, "The fragile X mental retardation protein binds specifically to its mRNA via a purine quartet motif," EMBO Journal, vol. 20, no. 17, pp. 4803-4813, 2001.

[27] S. Ceman, W. T. O'Donnell, M. Reed, S. Patton, J. Pohl, and S. T. Warren, "Phosphorylation influences the translation state of FMRP-associated polyribosomes," Human Molecular Genetics, vol. 12, no. 24, pp. 3295-3305, 2003.
[28] P. Jin, D. C. Zarnescu, S. Ceman et al., "Biochemical and genetic interaction between the fragile $\mathrm{X}$ mental retardation protein 3nd the microRNA pathway," Nature Neuroscience, vol. 7, no. 2, pp. 113-117, 2004.

[29] L. N. Antar, R. Afroz, J. B. Dictenberg, R. C. Carroll, and G. J. Bassell, "Metabotropic glutamate receptor activation regulates fragile $\mathrm{X}$ mental retardation protein and Fmr1 mRNA localization differentially in dendrites and at synapses," Journal of Neuroscience, vol. 24, no. 11, pp. 2648-2655, 2004.

[30] J. C. Darnell, C. E. Fraser, O. Mostovetsky et al., "Kissing complex RNAs mediate interaction between the fragile-X mental retardation protein $\mathrm{KH} 2$ domain and brain polyribosomes," Genes and Development, vol. 19, no. 8, pp. 903-918, 2005.

[31] N. Dolzhanskaya, G. Merz, J. M. Aletta, and R. B. Denman, "Methylation regulates the intracellular protein-protein and protein-RNA interactions of FMRP," Journal of Cell Science, vol. 119, no. 9, pp. 1933-1946, 2006.

[32] A. Aschrafi, B. A. Cunningham, G. M. Edelman, and P. W. Vanderklish, "The fragile $\mathrm{X}$ mental retardation protein and group I metabotropic glutamate receptors regulate levels of mRNA granules in brain," Proceedings of the National Academy of Sciences of the United States of America, vol. 102, no. 6, pp. 2180-2185, 2005.

[33] L. Hou, M. D. Antion, D. Hu, C. M. Spencer, R. Paylor, and E. Klann, "Dynamic translational and proteasomal regulation of fragile $\mathrm{X}$ mental retardation protein controls mGluRdependent long-term depression," Neuron, vol. 51, no. 4, pp. 441-454, 2006.

[34] J. C. Darnell, C. E. Fraser, O. Mostovetsky, and R. B. Darnell, "Discrimination of common and unique RNA-binding activities among fragile X mental retardation protein paralogs," Human Molecular Genetics, vol. 18, no. 17, pp. 3164-3177, 2009.

[35] M. Melko and B. Bardoni, "The role of G-quadruplex in RNA metabolism: involvement of FMRP and FMR2P," Biochimie, vol. 92, no. 8, pp. 919-926, 2010.

[36] F. Zalfa, M. Giorgi, B. Primerano et al., "The fragile X syndrome protein FMRP associates with BC1 RNA and regulates the translation of specific mRNAs at synapses," Cell, vol. 112, no. 3, pp. 317-327, 2003.

[37] E. W. Khandjian, M.-E. Huot, S. Tremblay, L. Davidovic, R. Mazroui, and B. Bardoni, "Biochemical evidence for the association of fragile $\mathrm{X}$ mental retardation protein with brain polyribosomal ribonucleoparticles," Proceedings of the National Academy of Sciences of the United States of America, vol. 101, no. 36, pp. 13357-13362, 2004.

[38] G. Stefani, C. E. Fraser, J. C. Darnell, and R. B. Darnell, "Fragile $\mathrm{X}$ mental retardation protein is associated with translating polyribosomes in neuronal cells," Journal of Neuroscience, vol. 24, no. 33, pp. 7272-7276, 2004.

[39] L. Davidovic, M.-E. Huot, and E. W. Khandjian, "Lost once, the fragile $\mathrm{X}$ mental retardation protein is now back onto brain polyribosomes," RNA Biology, vol. 2, no. 1, pp. e1-e3, 2005.

[40] F. Zalfa, S. Adinolfi, I. Napoli et al., "Fragile X mental retardation protein (FMRP) binds specifically to the brain cytoplasmic RNAs BC1/BC200 via a novel RNA-binding motif," Journal of Biological Chemistry, vol. 280, no. 39, pp. 33403-33410, 2005.

[41] H. Wang, A. Iacoangeli, D. Lin et al., "Dendritic BC1 RNA in translational control mechanisms," Journal of Cell Biology, vol. 171, no. 5, pp. 811-821, 2005.

[42] C. Gabus, R. Mazroui, S. Tremblay, E. W. Khandjian, and J.-L. Darlix, "The fragile X mental retardation protein has nucleic 
acid chaperone properties," Nucleic Acids Research, vol. 32, no. 7, pp. 2129-2137, 2004.

[43] H. Wang, A. Iacoangeli, S. Popp et al., "Dendritic BC1 RNA: functional role in regulation of translation initiation," Journal of Neuroscience, vol. 22, no. 23, pp. 10232-10241, 2002.

[44] H. Wang and H. Tiedge, "Translational control at the synapse," Neuroscientist, vol. 10, no. 5, pp. 456-466, 2004.

[45] I. A. Muslimov, A. Iacoangeli, J. Brosius, and H. Tiedge, "Spatial codes in dendritic BC1 RNA," Journal of Cell Biology, vol. 175, no. 3, pp. 427-439, 2006.

[46] F. Zalfa and C. Bagni, "Another view of the role of FMRP in translational regulation," Cellular and Molecular Life Sciences, vol. 62, no. 2, pp. 251-252, 2005.

[47] A. Iacoangeli, T. S. Rozhdestvensky, N. Dolzhanskaya et al., "On BC1 RNA and the fragile X mental retardation protein," Proceedings of the National Academy of Sciences of the United States of America, vol. 105, no. 2, pp. 734-739, 2008.

[48] J. G. Cheng, H. Tiedge, and J. Brosius, "Identification and characterization of BC1 RNP particles," DNA and Cell Biology, vol. 15, no. 7, pp. 549-559, 1996.

[49] V. Brown, K. Small, L. Lakkis et al., "Purified recombinant Fmrp exhibits selective RNA binding as an intrinsic property of the fragile X mental retardation protein," Journal of Biological Chemistry, vol. 273, no. 25, pp. 15521-15527, 1998.

[50] S. Adinolfi, C. Bagni, G. Musco, T. Gibson, L. Mazzarella, and A. Pastore, "Dissecting FMR1, the protein responsible for fragile X syndrome, in its structural and functional domains," RNA, vol. 5, no. 9, pp. 1248-1258, 1999.

[51] C. T. Ashley Jr., K. D. Wilkinson, D. Reines, and S. T. Warren, "FMR1 protein: conserved RNP family domains and selective RNA binding," Science, vol. 262, no. 5133, pp. 563-566, 1993.

[52] D. K. Price, F. Zhang, C. T. Ashley Jr., and S. T. Warren, "The chicken FMR1 gene is highly conserved with a CCT 5' untranslated repeat and encodes an RNA-binding protein," Genomics, vol. 31, no. 1, pp. 3-12, 1996.

[53] Z. Li, Y. Zhang, L. Ku, K. D. Wilkinson, S. T. Warren, and Y. Feng, "The fragile $\mathrm{X}$ mental retardation protein inhibits translation via interacting with mRNA," Nucleic Acids Research, vol. 29, no. 11, pp. 2276-2283, 2001.

[54] M.-C. Didiot, Z. Tian, C. Schaeffer, M. Subramanian, J.-L. Mandel, and H. Moine, "The G-quartet containing FMRP binding site in FMR1 mRNA is a potent exonic splicing enhancer," Nucleic Acids Research, vol. 36, no. 15, pp. 49024912, 2008.

[55] R. B. Denman, "mRNPs take shape by CLIPPING and PAIRING," BioEssays, vol. 28, no. 11, pp. 1132-1143, 2006.

[56] A. Stetler, C. Winograd, J. Sayegh et al., "Identification and characterization of the methyl arginines in the fragile X mental retardation protein Fmrp," Human Molecular Genetics, vol. 15, no. 1, pp. 87-96, 2006.

[57] R. B. Denman and Y. J. Sung, "Species-specific and isoformspecific RNA binding of human and mouse fragile X mental retardation proteins," Biochemical and Biophysical Research Communications, vol. 292, no. 4, pp. 1063-1069, 2002.

[58] W. Xie, N. Dolzhanskaya, G. LaFauci, C. Dobkin, and R. B. Denman, "Tissue and developmental regulation of fragile $\mathrm{X}$ mental retardation 1 exon 12 and 15 isoforms," Neurobiology of Disease, vol. 35, no. 1, pp. 52-62, 2009.

[59] F. Zalfa, T. Achsel, and C. Bagni, "mRNPs, polysomes or granules: FMRP in neuronal protein synthesis," Current Opinion in Neurobiology, vol. 16, no. 3, pp. 265-269, 2006.

[60] C. Bagni, "On BC1 RNA and the fragile X mental retardation protein," Proceedings of the National Academy of Sciences of the United States of America, vol. 105, no. 17, p. E19, 2008.
[61] E. Bechara, L. Davidovic, M. Melko et al., "Fragile X related protein 1 isoforms differentially modulate the affinity of fragile X mental retardation protein for G-quartet RNA structure," Nucleic Acids Research, vol. 35, no. 1, pp. 299-306, 2007.

[62] L. Menon and M. Mihailescu, "Interactions of the G quartet forming semaphorin 3F RNA with the RGG box domain of the fragile X protein family," Nucleic Acids Research, vol. 35, no. 16, pp. 5379-5392, 2007.

[63] K. Zou, J. Liu, N. Zhu et al., "Identification of FMRPassociated mRNAs using yeast three-hybrid system," American Journal of Medical Genetics, vol. 147, no. 6, pp. 769-777, 2008.

[64] R. B. Denman, "The FMRP-BC1 RNA controversy: tempest in a teapot or symptomatic of a larger problem," in The Molecular Basis of Fragile X Syndrome, Y. J. Sung and R. B. Denman, Eds., pp. 65-79, Research Signpost, Trivandrum, India, 2005.

[65] T. S. Rozhdestvensky, A. M. Kopylov, J. Brosius, and A. Huttenhofer, "Neuronal BC1 RNA structure: evolutionary conversion of a tRNA(Ala) domain into an extended stemloop structure," RNA, vol. 7, no. 5, pp. 722-730, 2001.

[66] N. Dolzhanskaya, G. Merz, and R. B. Denman, "Alternative splicing modulates protein arginine methyltransferasedependent methylation of fragile X syndrome mental retardation protein," Biochemistry, vol. 45, no. 34, pp. 10385-10393, 2006.

[67] W. C. Boelens, E. J. R. Jansen, W. J. van Venrooij, R. Stripecke, I. W. Mattal, and S. I. Gunderson, "The human U1 snRNPspecific U1A protein inhibits polyadenylation of its own premRNA," Cell, vol. 72, no. 6, pp. 881-892, 1993.

[68] M. A. Kiebler and G. J. Bassell, "Neuronal RNA granules: movers and makers," Neuron, vol. 51, no. 6, pp. 685-690, 2006.

[69] A. Ramos, D. Hollingworth, and A. Pastore, "G-quartetdependent recognition between the FMRP RGG box and RNA," RNA, vol. 9, no. 10, pp. 1198-1207, 2003.

[70] K. J. Zanotti, P. E. Lackey, G. L. Evans, and M.-R. Mihailescu, "Thermodynamics of the fragile $\mathrm{X}$ mental retardation protein RGG box interactions with G quartet forming RNA," Biochemistry, vol. 45, no. 27, pp. 8319-8330, 2006.

[71] H. Wang, L. Ku, D. J. Osterhout et al., "Developmentallyprogrammed FMRP expression in oligodendrocytes: a potential role of FMRP in regulating translation in oligodendroglia progenitors," Human Molecular Genetics, vol. 13, no. 1, pp. 7989, 2004.

[72] R. B. Denman, "Protein methyltransferase activities in commercial in vitro translation systems," Journal of Biochemistry, vol. 144, no. 2, pp. 223-233, 2008.

[73] J. D. Gary and S. Clarke, "RNA and protein interactions modulated by protein arginine methylation," Progress in Nucleic Acid Research and Molecular Biology, vol. 61, pp. 65131, 1998.

[74] C. D. Krause, Z.-H. Yang, Y.-S. Kim, J.-H. Lee, J. R. Cook, and S. Pestka, "Protein arginine methyltransferases: evolution and assessment of their pharmacological and therapeutic potential," Pharmacology and Therapeutics, vol. 113, no. 1, pp. 50-87, 2007.

[75] E. W. Khandjian, "Biology of the fragile X mental retardation protein, an RNA-binding protein," Biochemistry and Cell Biology, vol. 77, no. 4, pp. 331-342, 1999.

[76] A. Ramos, D. Hollingworth, S. Adinolfi et al., "The structure of the N-terminal domain of the fragile X mental retardation protein: a platform for protein-protein interaction," Structure, vol. 14, no. 1, pp. 21-31, 2006.

[77] D. Herschlag, "RNA chaperones and the RNA folding problem," Journal of Biological Chemistry, vol. 270, no. 36, pp. 20871-20874, 1995. 
[78] H. De Rocquigny, C. Gabus, A. Vincent, M.-C. FournièZaluski, B. Roques, and J.-L. Darlix, "Viral RNA annealing activities of human immunodeficiency virus type 1 nucleocapsid protein require only peptide domains outside the zinc fingers," Proceedings of the National Academy of Sciences of the United States of America, vol. 89, no. 14, pp. 6472-6476, 1992. 

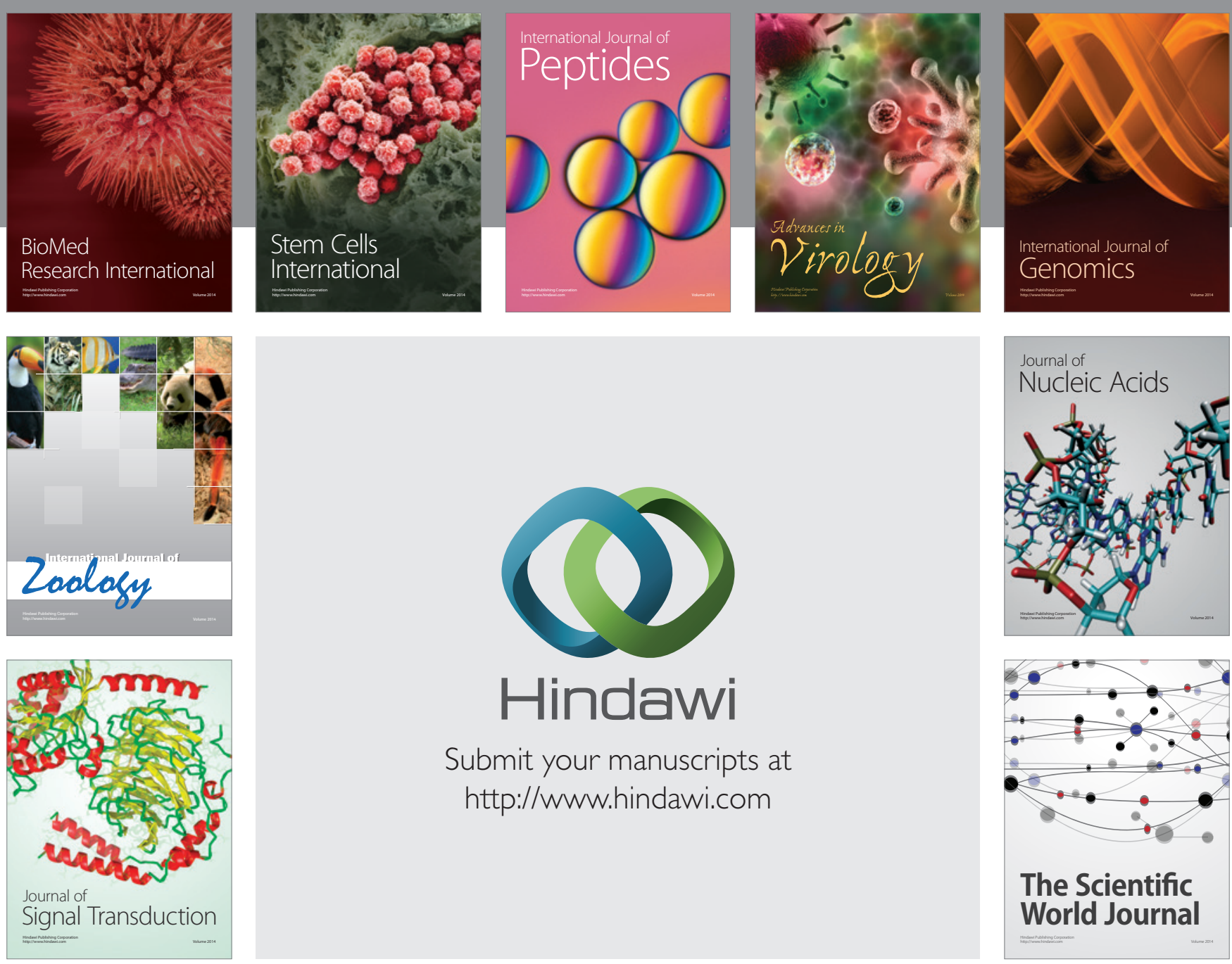

Submit your manuscripts at

http://www.hindawi.com
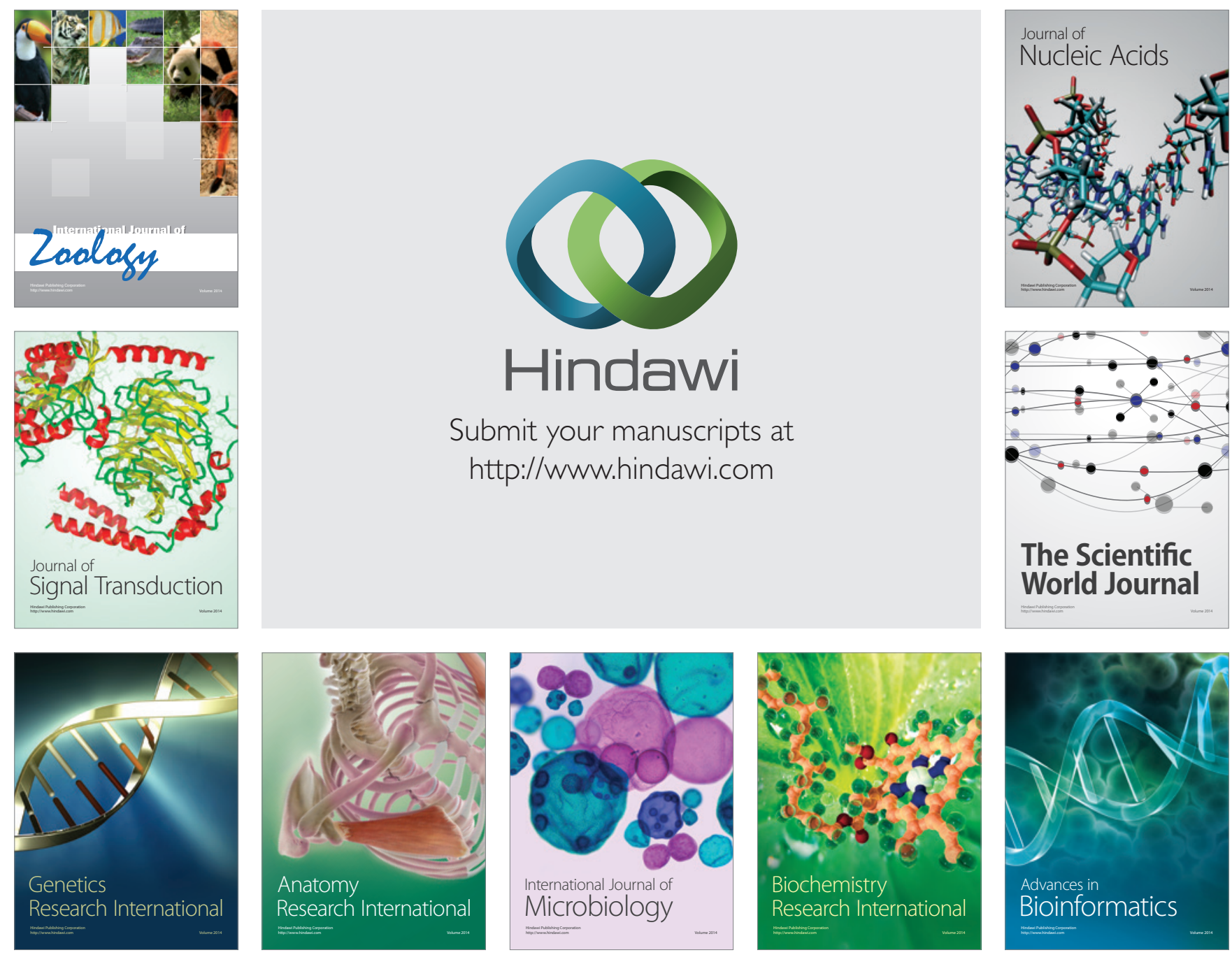

The Scientific World Journal
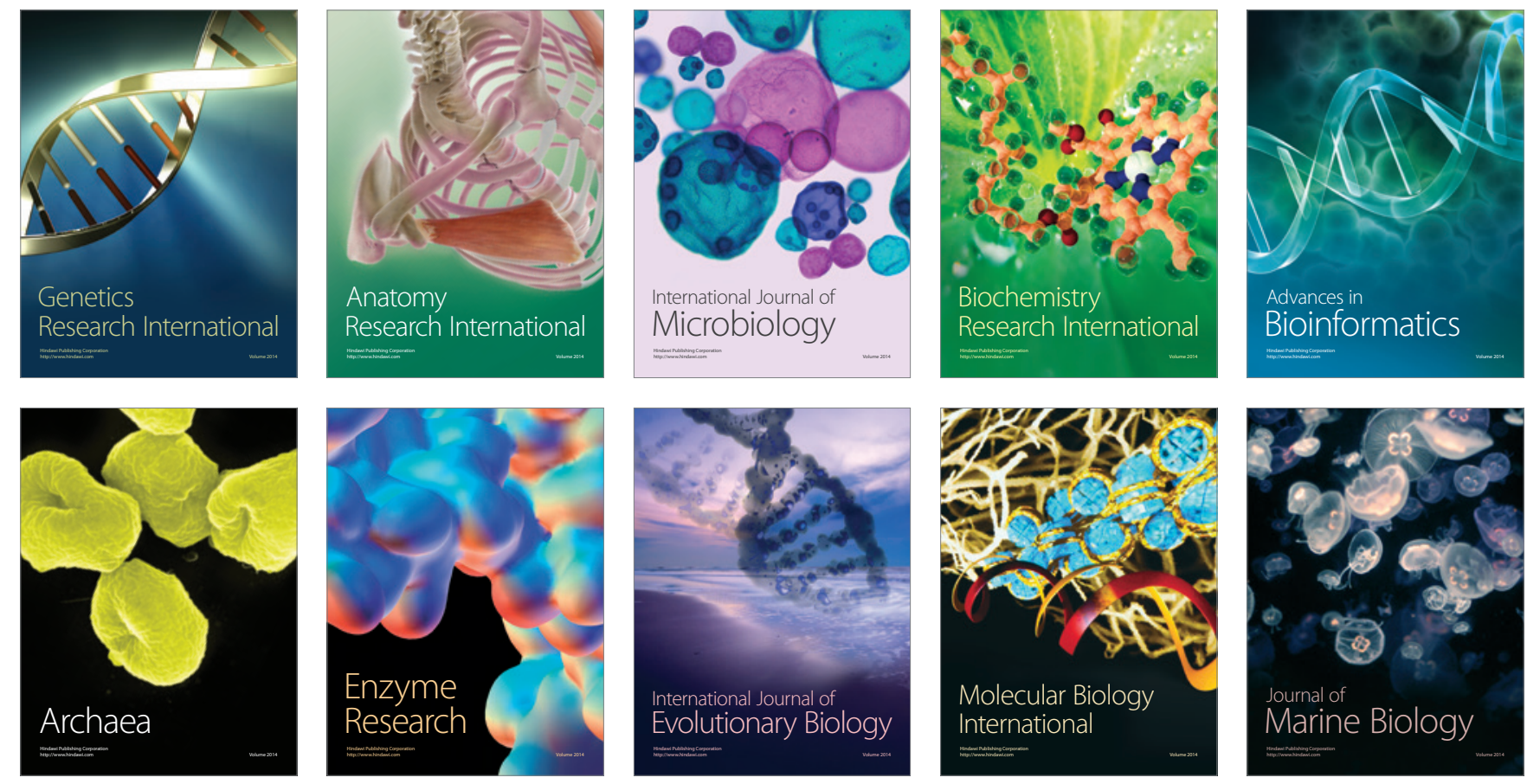